\title{
Coupled Terrestrial Carbon and Water Dynamics in Terrestrial Ecosystems: Contributions of Remote Sensing
}

\author{
Baozhang Chen \\ Institute of Geographic Sciences and Nature Resources Research, \\ Chinese Academy of Sciences, Beijing \\ P.R. China
}

\section{Introduction}

The Earth climate is a complex, interactive system, determined by a number of complex connected physical, chemical and biological processes occurring in the atmosphere, land and ocean. The terrestrial biosphere plays many pivotal roles in the coupled Earth system providing both positive and negative feedbacks to climate change (Treut et al., 2007). Terrestrial vegetation via photosynthesis converts solar energy into carbon that would otherwise reside in the atmosphere as a greenhouse gas, thereby regulating climate. Vegetation also transfers water between belowground reservoirs and the atmosphere to maintain precipitation and surface water flows.The terrestrial carbon (C) cycle is closely linked to hydrological and nutrient controls on vegetation (Betts et al., 2000; Cox et al., 2000). Understanding the coupled terrestrial $C$ and water cycle is required to gain a comprehensive understanding of the role that terrestrial ecosystems play in the global climate change. Much progress has been made in gaining insight of the coupling processes between $C$ and water cycles across a range of time and spatial scales (Pielke Sr, 2001; Friedlingstein et al., 2003; Seneviratne et al., 2006; Betts et al, 2007a,b; Baldocchi, 2008). Since the early 1990s, there has been an increased interest in monitoring of the $\mathrm{CO}_{2}$, water vapor and energy exchange between the atmosphere and terrestrial ecosystems by a variety of methods, such as the eddy-covariance techniques (EC), satellite and other airborne remote sensing, $\mathrm{CO}_{2}$ concentration and isotope measurements. Meanwhile, there are various kinds of models have been developed to better understanding of these processes and for largescale $\mathrm{C}$ and water budgeting.

Remote sensing (RS) from satellite and airborne platforms, along with many other sources of land ground-based measurements (e.g., eddy covariance flux tower network, biometric plots, radar network, etc.) is playing and will continue to play a vital role in better understanding the coupled C and water cycle. Satellite RS allows the study of ecosystems from a completely new vantage point, facilitating a holistic perspective like viewing the Earth does for astronauts. Satellite-borne RS offers unique opportunities to parameterize land surface characteristics over large spatial extents at variable spatial and temporal resolutions. While there are challenges relating RS data recorded in radiance or backscatter 
to variables of interest, and RS has poor temporal resolution compared to ground-based measurement devices, RS and spatial analytical techniques and distributed biogeochemical modeling embedded in Geographical Information Systems (GIS) have allowed us to better understand the coupled $\mathrm{C}$ and hydrological dynamics across a large range of temporal and spatial scales.

The large number of papers published since the 1980s on the terrestrial and C/water cycles have resulted in the publication of several major reviews from different perspectives. For example, Running et al. (2004) described a blueprint for more comprehensive coordination of the various flux measurement and modeling activities into a global terrestrial monitoring network by reviewing the literature published before the middle of 1990s. Baldocchi (2008) recently provided a comprehensive review of research results associated with a global network of $\mathrm{C}$ flux measurements systems. The topics discussed by this review include history of the network, errors and issues related with the EC method, and a synopsis of how these data are being used by ecosystem and climate modellers and the remote-sensing community (Baldocchi, 2008). Kalma et al. (2008) reviewed satellite-based algorithms for estimating evepotranspiration (ET) and land surface temperatures at local, regional and continental scales, with particular emphasis on studies published since the early 1990s; while Verstraeten et al. (2008) provided a comprehensive review of remote sensing methods for assessing ET and soil moisture content across different scales based on the literature published after 1990s. Marquis and Tans (2008) reviewed satellite-based instruments on $\mathrm{CO}_{2}$ concentration measurements.

In this chapter, I distil and synthesise the rapidly growing literature on $\mathrm{C}$ and water cycles using remote sensing in direct or indirect ways across local to global spatial scales and over a range of time scales. To give the reader a perspective of the growth of this literature, a search of Web of Science produced over 1500 papers with the key words 'ecosystem carbon, water cycles and remote sensing' published since 1990 which is indicative of the large amount of research recently being undertaken on these topics. In order to filter through this large body of literature, I concentrate on papers discussing on the coupling processes between $C$ and water and I extract information from a database of published results that I have collated during the past decade (available on request). In terms of content, the report covers the state of knowledge, monitoring and modeling of the coupled terrestrial $\mathrm{C}$ and water cycles. My aim is to highlight the recent advances in this field, and propose areas of future research based on perceived current gaps in the literature.

This is a synthesis of state-of-the-art research on how RS has informed the study of coupled $\mathrm{C}$ and hydrology cycles. The review is divided into several inter-connected sections. First, I review the scientific background of the linkage between terrestrial ecosystems and climate, and revise the state of knowledge on terrestrial $\mathrm{C}$ cycling, coupling of the $\mathrm{C}$ and water cycles. Second, I discuss the ground-based and satellite-based monitoring methods and observation networks associated with measuring $\mathrm{C}$ and water fluxes, $\mathrm{CO}_{2}$ concentration and $\mathrm{C}$ isotopes. Third, I report on the recent advances in modeling approaches associated with the terrestrial biochemical and hydrological studies. Fourth, I discuss research gaps in C sinks/sources estimates and finally, I discuss the current research trends and the near-future directions in this field and propose an upscaling framework for landscape and regional $\mathrm{C}$ and water fluxes estimates. 


\section{Scientific background and state of knowledge}

\subsection{Overview of terrestrial ecosystems and climate}

The climate system is controlled by a number of complex coupled physical, chemical and biological processes (Figure 1). The terrestrial biosphere plays a crucial role in the climate system, providing both positive and negative feedbacks to climate change through biogeophysical and biogeochemical processes (Treut et al., 2007). Couplings between the climate system and biogeochemistry are mainly through tightly linked dynamics of $\mathrm{C}$ and water cycles. The importance of coupled $\mathrm{C}$ and water dynamics for the climate system has been increasingly recognized (Cox et al., 2000; Pielke Sr, 2001; Friedlingstein et al., 2003; Seneviratne et al., 2006; Betts et al, 2000, 2007a,b); however the mechanisms behind these coupled cycles are still far from well understood.

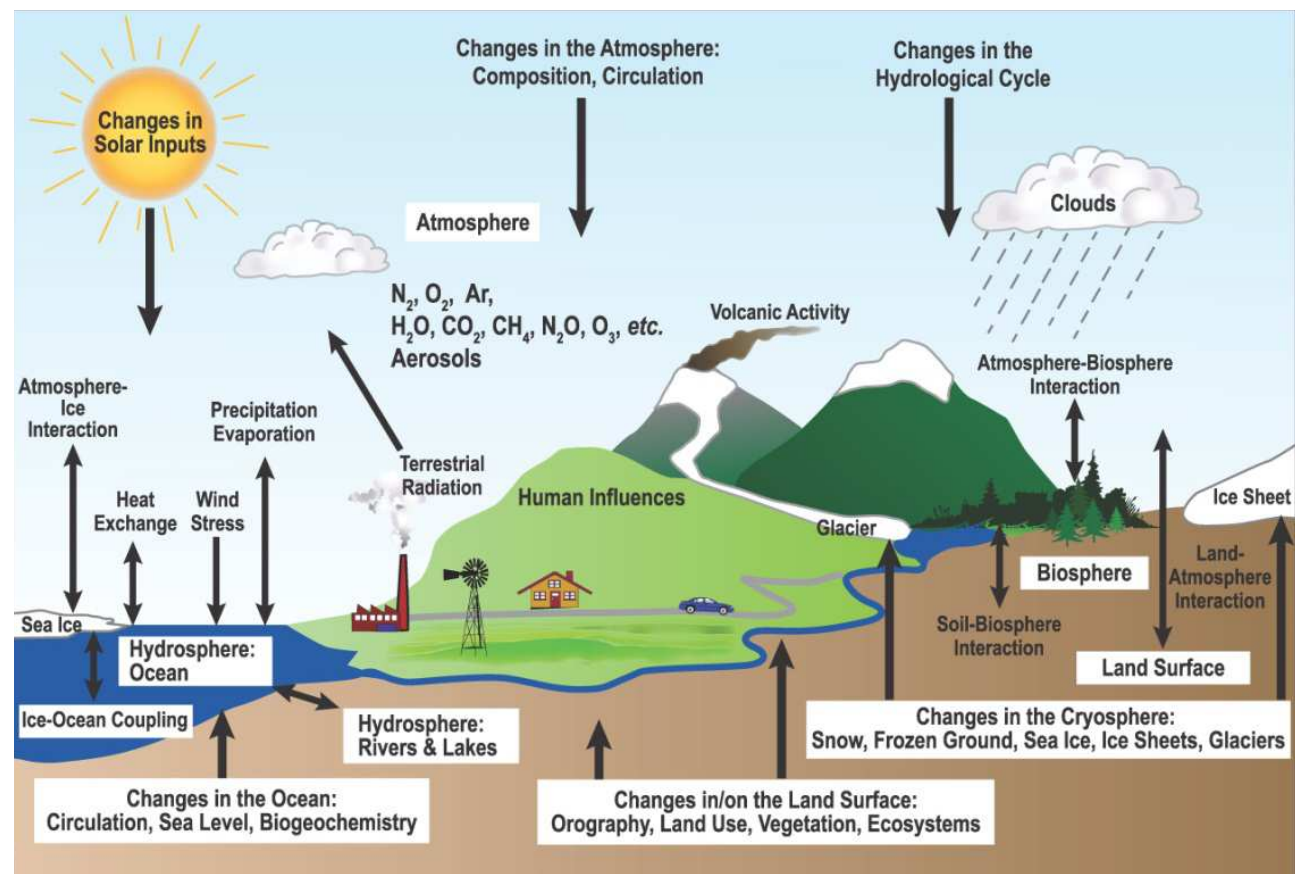

Fig. 1. Schematic view of the components of the climate system, their processes and interactions (Treut et al., 2007).

\subsection{Terrestrial C cycling}

One of the crucial issues in the prognosis of future climate change is the global budget of atmospheric $\mathrm{CO}_{2}$. The growth rate of atmospheric $\mathrm{CO}_{2}$ is increasing rapidly. Three processes contribute to this rapid increase: fossil fuel emission, land use change (deforestation), and ocean and terrestrial uptake. As shown in Figure 2, terrestrial $\mathrm{C}$ budgets have large uncertainties and interannual variability.

Terrestrial ecosystems mediate a large part of $\mathrm{CO}_{2}$ flux between the Earth's surface and the atmosphere, with $\sim 120 \mathrm{Pg} \mathrm{C} \mathrm{yr}^{-1}$ taken up by photosynthesis and roughly the same amount 


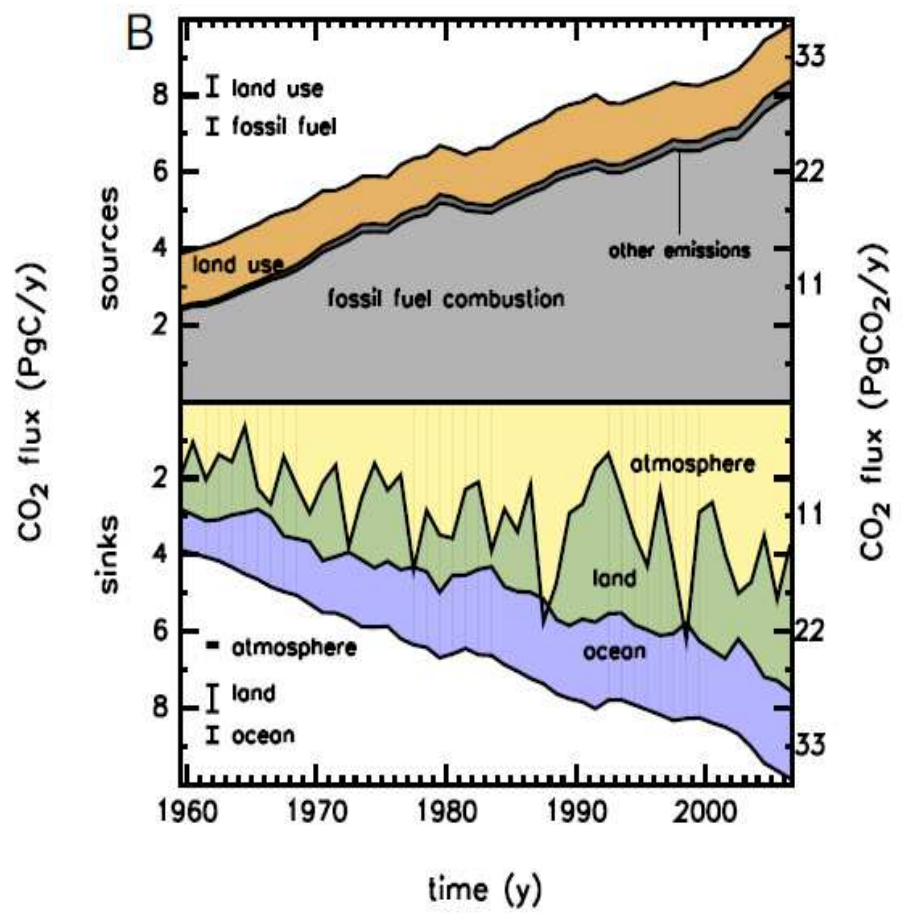

Fig. 2. Global $\mathrm{CO}_{2}$ budget from 1959 to 2006. Upper panel: $\mathrm{CO}_{2}$ emissions to the atmosphere (sources) as the sum of fossil fuel combustion, land-use change, and other emissions. Lower panel: The fate of the emitted $\mathrm{CO}_{2}$, including the increase in atmospheric $\mathrm{CO}_{2}$ plus the sinks of $\mathrm{CO}_{2}$ on land and in the ocean (Canadell et al., 2007).

released back to the atmosphere by respiration annually (Treut et al., 2007; Prentice et al., 2001). Imbalances between gross ecosystem photosynthesis or gross primary productivity (GPP) and ecosystem respiration $\left(R_{e}\right)$ lead to land surfaces being either $\mathrm{CO}_{2}$ sinks or sources. The magnitudes of sinks and sources have fluctuated on annual and longer time scales due to variable climate, land use change, disturbance, and changes in the age distribution and species composition of ecosystems (Battle et al., 2000; Arain et al., 2002; Law et al., 2002; Morgenstern et al., 2004; Humphreys et al., 2005, 2006; Urbanski et al., 2007). Terrestrial ecosystems modify atmospheric $C$ balance through many mechanisms. A detailed understanding of the interactive relationships in atmosphere-biosphere exchange is relevant to ecosystem-scale analysis and is needed to improve our knowledge of the global C cycle (Falk et al., 2008).

In recent years, scientists have learnt that terrestrial ecosystems' vegetation, soil (Melillo et al., 1989; Knapp et al., 1993) and animals (Naeem et al., 1995; Hattenschwiler and Bretscher, 2001) play key roles in mediating the terrestrial $\mathrm{C}$ cycle. Plants being the primary producers, it is from them that mass and energy gets transformed to other living organisms (Engel and Odum, 1999) within an ecosystem. The process of photosynthesis fixes atmospheric C into the biosphere. Atmospheric $\mathrm{CO}_{2}$ enters the plant through stomatal opening that is controlled by a variety of environmental factors (Jarvis, 1976; Griffis et al., 2003). These factors include ambient temperature, atmospheric $\mathrm{CO}_{2}$ concentration, nutrient availability, soil water availability and 
forest age (Schimel, 1995; Prentice et al., 2001). Changes in the atmospheric $\mathrm{CO}_{2}$ concentration and the corresponding changes in the climate have altered the magnitudes of terrestrial $\mathrm{C}$ cycling. For example, a climate change induced increases in vegetation growth due to earlier springs and lengthened growing seasons were detected by the phase shift of seasonal atmospheric $\mathrm{CO}_{2}$ cycle by Keeling et al. (1996) and satellite-based vegetation index analysis by Myneni et al. (1997). Studies indicate that an increase in atmospheric $\mathrm{CO}_{2}$ enhances photosynthesis (e.g. Woodward and Friend, 1988) and hence increases assimilation of atmospheric $\mathrm{CO}_{2}$ by the terrestrial vegetation. Nitrogen $(\mathrm{N})$ availability to plants is another factor that can affect photosynthesis. This is because $\mathrm{N}$ is a primary nutrient for plant growth. In the recent years, variations in plant $\mathrm{N}$ availability have also altered the trends in the terrestrial $\mathrm{C}$ cycles. Variations in plant $\mathrm{N}$ availability occur mainly due to natural and anthropogenic N-deposition. Based on modeling studies, e.g., researchers (Townsend et al., 1996; Asner et al., 1997; and Holland et al., 1997) have demonstrated that $\mathrm{N}$ deposition is

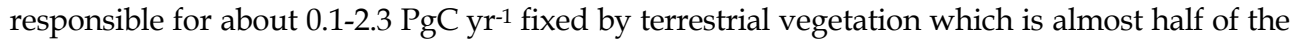
magnitude of $C$ flux due to fossil fuel emission. Another factor that determines the nature of terrestrial C balance of an ecosystem is the age of the vegetation. Schimel et al. (1995) have demonstrated that forest re-growth can account for part of terrestrial $\mathrm{C}$ uptake as much as 0.5 $\pm 0.5 \mathrm{PgC}_{\mathrm{yr}}^{-1}$, especially in northern mid and high latitudes. This is because younger vegetation actively grows and hence sequesters more atmospheric $\mathrm{CO}_{2}$ as opposed to mature forest stands. There are many other processes that directly and indirectly affect photosynthesis and thus, the $C$ cycle. They include land use and land cover change (Caspersen et al., 2000; Houghton and Hackler, 2006; Easter et al., 2007), reforestation (House et al., 2002; Paul et al., 2002), agricultural and grazing activities (Cerri et al., 2005), insect attack (Chapman et al., 2003; Throop et al., 2004) and invasive species (Szlavecz et al., 2006). Respiration is a process by which $\mathrm{C}$ is added to the atmosphere from the biosphere. There are studies that indicate that total ecosystem respiration is a major determinant of terrestrial $\mathrm{C}$ balances (Valentini et al., 2000). Total ecosystem respiration includes respiration by aboveground plant parts (boles, branches, twigs, and leaves) and soil respiration, which is the sum of the heterotrophic respiration, and root respiration including respiration of symbiotic microorganisms. The temporal variability of respiratory metabolism is influenced mostly by temperature and humidity conditions (Davidson and Janssens, 2006). Although ecosystem respiration has received considerable attention in recent decades, much less is known about the relative contributions of its sub- components (Jassal et al., 2007), and our understanding of how they will respond to global warming is poor. Soil respiration (root + heterotrophic respiration) is a dominant component of $\mathrm{C}$ exchange in terrestrial ecosystems which accounts for more than half of the total ecosystem respiration (Black et al. 2005). This is because soils of terrestrial ecosystems contain more $\mathrm{C}$ than the atmosphere and live biomass together (Eswaran et al., 1993). Components of respiration can have different responses to temperature and soil water content (Boone et al., 1998; Lavigne et al., 2004), thus the effects of these environmental controls needs to be understood in order to fully comprehend the soil $\mathrm{C}$ cycling mechanism. There are many other mechanisms that can release terrestrial $C$ to atmosphere. This includes both natural and anthropogenic reasons. Emission of large amounts of $C$ to the atmosphere from vegetation can occur during forest fires (Amiro et al., 2002; Soja et al., 2004; Amiro et al., 2004) or biomass burning (Fernandez et al., 1999; Tanaka et al., 2001). These C emissions are of very high magnitudes although their duration is very short. Forest fires and biomass burning also affect the nutrient status of the soil which could have positive effects on the succeeding vegetation (Prietofernandez et al., 1993; Deluca and Sala, 2006). Another form of C flux in 
almost all terrestrial ecosystems is the import and export of dissolved organic carbon (DOC) (Neff and Asner 2001; Hornberger et al. 1994). DOC fluxes include C in the form of simple amino acids to large molecules that are transported through water flows. Fluxes of DOC into the ocean via runoff from terrestrial ecosystems are estimated to be 0.2 (Harrison et al., 2005) to $0.4 \mathrm{Pg} \mathrm{C}$ per year (IPCC, 2001). Since these fluxes are very small compared to the $C$ fluxes due ecosystem is a net $\mathrm{C}$ sink due to the presence of soil C-pools having much longer residence times (Thompson et al., 1996; Chen et al., 2003; Canadell et al., 2007; Schulze, 2006). The strength of the terrestrial $\mathrm{C}$ sink was estimated to be 0.5-2.0 $\mathrm{Pg} \mathrm{C} \mathrm{yr}^{-1}$ (Schimel et al., 1995). By sequestering atmospheric $C$, the terrestrial ecosystems help decrease the rate of accumulation of anthropogenic $\mathrm{CO}_{2}$ in the atmosphere, and its associated climate change (Cihlar, 2007). Terrestrial $\mathrm{C}$ sinks may be responsible for taking up about one-third of all the $\mathrm{CO}_{2}$ that is released into the atmosphere (Canadell et al., 2007). The terrestrial $C$ sink, inferred based on our current understanding, may not be permanent (Luo et al., 2003; Cox et al., 2000 ; Friedlingstein et al., 2003). Over the last few years there have been several studies suggesting that the size of this terrestrial C sink is vulnerable to global warming (Martin et al., 1998; Nemani et al., 2002; Canadell et al., 2007). The metabolism of terrestrial ecosystems is complex and highly dynamic because ecosystems consist of coupled, non-linear processes that possess many positive and negative feedbacks (Levin, 2002; Ma et al. 2007). How the C budget of major ecosystems will respond to changes in climate is not quantitatively well understood (Baldocchi \& Meyers 1998, Goulden et al., 1998; Black et al., 2000; Baldocchi et al., 2001a; Baldocchi \& Wilson, 2001; Law et al., 2002; Barr et al., 2004, 2007). A detailed understanding of the interactive relationships in atmosphere-biosphere exchange is relevant to ecosystem-scale analysis and is needed to improve our knowledge of the global C cycle (Falk,M et al., 2008). The metabolism of terrestrial ecosystems is complex and highly dynamic because ecosystems consist of coupled, non-linear processes that possess many positive and negative feedbacks (Levin et al., 2002; Ma et al., 2007). Complex features of ecosystem metabolism are relatively unknown and how $\mathrm{C}$ budget of major ecosystems will respond to changes in climate is not quantitatively well understood (Black et al., 2000; Baldocchi et al., 2001; Baldocchi et al.,2001; Barr et al., 2004; Law et al., 2002).

\subsection{Terrestrial water cycling}

Most of the Earth is covered by water, amounting to more than one billion $\mathrm{km}^{3}$. The vast majority of that water, however, is in forms unavailable to land-based or freshwater ecosystems. Less than 3 percent is fresh enough to drink or to irrigate crops, and of that total, more than two-thirds is locked up in glaciers and ice caps. Freshwater lakes and rivers hold $100,000 \mathrm{~km}^{3}$ globally, less than one ten-thousandth of all water on earth (Jackson et al, 2001).

Water vapor in the atmosphere exerts an important influence on climate and on the water cycle, even though only $15,000 \mathrm{~km}^{3}$ of water is typically held in the atmosphere at any time. This tiny fraction, however, is vital for the biosphere. Water vapor is the most important of the so-called greenhouse gases (others include $\mathrm{CO}_{2}, \mathrm{CH}_{4}$ and $\mathrm{N}_{2} \mathrm{O}$ ) that warm the Earth by trapping heat in the atmosphere. Water vapor contributes approximately two-thirds of the total warming that greenhouse gases supply. Without these gases, the mean surface temperature of the earth would be well below freezing, and liquid water would be absent over much of the planet. Equally important for life, atmospheric water turns over every ten days or so as water vapor condenses and falls as rain to the Earth and the heat of the Sun evaporates new supplies of vapor from the liquid reservoirs on earth. Solar energy typically 
evaporates about $425,000 \mathrm{~km}^{3}$ of ocean water each year. Most of this water returns back directly to the oceans as precipitation, but approximately $10 \%$ falls on land. If this were the only source of rainfall, average precipitation across the earth's land surfaces would be only $25 \mathrm{~cm}$ a year, a value typical for deserts or semi-arid regions. Instead, a second, larger source of water is recycled from plants and the soil through evapotranspiration. The water vapor from this source creates a direct feedback between the land surface and regional climate. This second source of recycled water contributes two-thirds of the $70 \mathrm{~cm}$ of precipitation that falls over land each year. Taken together, these two sources account for the $110,000 \mathrm{~km}^{3}$ of renewable freshwater available each year for terrestrial, freshwater, and estuarine ecosystems. Because the amount of rain that falls on land is greater than the amount of water that evaporates from it, the extra $40,000 \mathrm{~km}^{3}$ of water returns to the oceans, primarily via rivers and underground aquifers. A number of factors affect how much of this water is available for human use on its journey to the oceans. These factors include whether the precipitation falls as rain or snow, the timing of precipitation relative to patterns of seasonal temperature and sunlight, and the regional topography. For example, in many mountain regions, most precipitation falls as snow during winter, and spring snowmelt causes peak flows that flood major river systems. In other regions, excess precipitation percolates into the soil to recharge ground water or is stored in wetlands.

\subsection{Coupling of the $\mathrm{C}$ and water cycles}

The cycling of other materials such as $\mathrm{C}$ and $\mathrm{N}$ is strongly coupled to this water flux through the patterns of plant growth and microbial decomposition, and this coupling creates additional feedbacks between vegetation and climate. Thermodynamically, a terrestrial ecosystem is an open system. Therefore, hydrological and $\mathrm{C}$ cycles are closely coupled at various temporal and spatial scales (Betts, 2007; Ball et al., 1987; Levis et al., 1999; Rodriguez-Iturbe, 2000; Joos, 2001; Arain et al., 2006; Blanken and Black, 2004; Snyder 2004). C uptake for example, is closely coupled to water loss by ecosystems mainly through leaf stomatal pathway governed principally through leaf conductance (Jarvis, 1976; Harris et al., 2004; Rodriguez-Iturbe, 2001). Soil organic $\mathrm{C}$ decomposition is very sensitive to soil moisture content via microbial activity and other processes (Betts, 2007; Levis 1999; Snyder et al., 2004; Parton et al., 1993; D'odorico 2004). The flux of terrestrial organic $C$ by river runoff to the ocean and wetland discharge is an important component of the global organic C cycle (Hedges, 1992; Wang et al., 2004). It is estimated that $0.25 \times 10^{15} \mathrm{~g}$ dissolved organic carbon (DOC) is discharged to the ocean by the world rivers each year (Meybeck, 1982). The land surface hydrological processes (in particular the terrestrial river systems) play an important role in transport of dissolved and particulate organic C from terrestrial to marine ecosystems (Wang et al., 2004). However, the interactions between $C$ and water cycles and the mechanisms how these interactions will shape future climatic and biosphere conditions are far from well understood.

\section{The array of airborne and satellite sensors developed for monitoring of the coupled $C$ and water cycles}

\subsection{Satellite monitoring}

RS is the observation of a phenomenon from a distance, using devices that detect electromagnetic radiation. Satellite-borne remote sensing offers unique opportunities to parameterize land surface characteristics over large spatial extents at variable spatial and 
temporal resolutions. There has been a substantial increase in the number of satellite sensors for Earth observations that cover a large range of the electromagnetic radiation spectrum (Tables 1 and 2) since 1960s when the earlier Landsat satellites were launched into orbit, such as the Television Infrared Observation Satellite (TIROS-1) launched in 1960. None of these sensors have been designed exclusively for C, water or vegetation applications. For example, the TIROS- 1 was focused on weather analysis and forecasting (Natl. Res. Counc., 2008). However, scientists were applying these observations to vegetation studies by the next decade (Rouse et al., 1974; Tucker et al., 1979). Tuker et al. (1986) exploited the properties of chlorophyll pigments to absorb wavelengths in the red spectral region and structural properties of leaves to reflect near-infrared spectra based on the imagery data obtained by the Advanced Very High Resolution Radiometer (AVHRR) sensor onboard TIROS. This pioneer study that synoptic view of the coupled atmosphere-biosphere as C sequestration by photosynthesis from the atmosphere in the Northern Hemisphere (Tuker et al., 1986) opened possibilities for global perspectives in ecology. The first Landsat satellite launched in 1972 carried the Multispectral Scanner System (MSS) sensors which were specifically designed to map land resources with finer spatial resolution $(68 \mathrm{~m} \times 82 \mathrm{~m})$ than the AVHRR. The program was the first civil, non-weather satellite program and Landsat provided observations for any place on Earth once every 18 days, offering a wide range of studies on terrestrial vegetation and $C$ and water cycles. The Landsat Thematic Mapper sensors carried onboard the Landsat series of satellites, acquire images at a 30-m spatial resolution with a 16-day interval. The acquired data have been the backbone for land-cover, vegetation and C cycle studies. NASA's Earth Observing System (EOS), launched in 1999 (Tilford S. 1984), brought new capabilities for monitoring vegetation productivity and other properties with near-daily and global coverage. The multispectral sensors---Moderate Resolution Imaging Spectroradiometer (MODIS), onboard the EOS platform, have built invaluable global observation dataset for $C$ and water cycles research since the early 2000s. MODIS provides a global coverage every 1-2 days with 36 bands. The spatial resolution of MODIS (pixel size at nadir) is $250 \mathrm{~m}$ for channels 1 and $2(0.6 \mu \mathrm{m}-0.9 \mu \mathrm{m}), 500 \mathrm{~m}$ for channels 3 to $7(0.4 \mu \mathrm{m}-2.1 \mu \mathrm{m})$ and $1000 \mathrm{~m}$ for channels 8 to $36(0.4 \mu \mathrm{m}-14.4 \mu \mathrm{m})$, respectively. Data from the satellite-borne MODIS are currently used in the calculation of global weekly GPP and ET at 1-km spatial resolution (Running et al., 2004).

Sensors that have potential applications in $C$ and hydrology studies fall into two groups--optical (Table 1) and microwave (Table 2). Optical sensors cannot penetrate vegetation or clouds. In contrast, microwave sensors are able to penetrate vegetation and can collect data independently of cloud cover and solar illumination. This is important because it is difficult to acquire cloud-free imagery using optical sensors. There are two types of microwave sensors: active sensors and passive sensors. The former send and receive their own energy; while the latter detect the microwaves emitted by the Earth's surface. The microwave bands, being useful for vegetation and carbon and water cycles, are $\mathrm{K}, \mathrm{X}, \mathrm{C}$, and $\mathrm{L}$, ranked in increasing wavelengths. $\mathrm{K}$ - and $\mathrm{X}$-bands are useful for detecting surface temperature, snow density, and rainfall rates, whereas C- and L-bands are sensitive to soil moisture (Sass and Greed, 2011).

\subsection{Other airborne measurements}

Besides satellite monitoring, other airborne observation techniques (e.g. aircraft, airplane and land surface remote sensing) have been developed rapidly since the latest decade. 
Coupled Terrestrial Carbon and Water Dynamics in

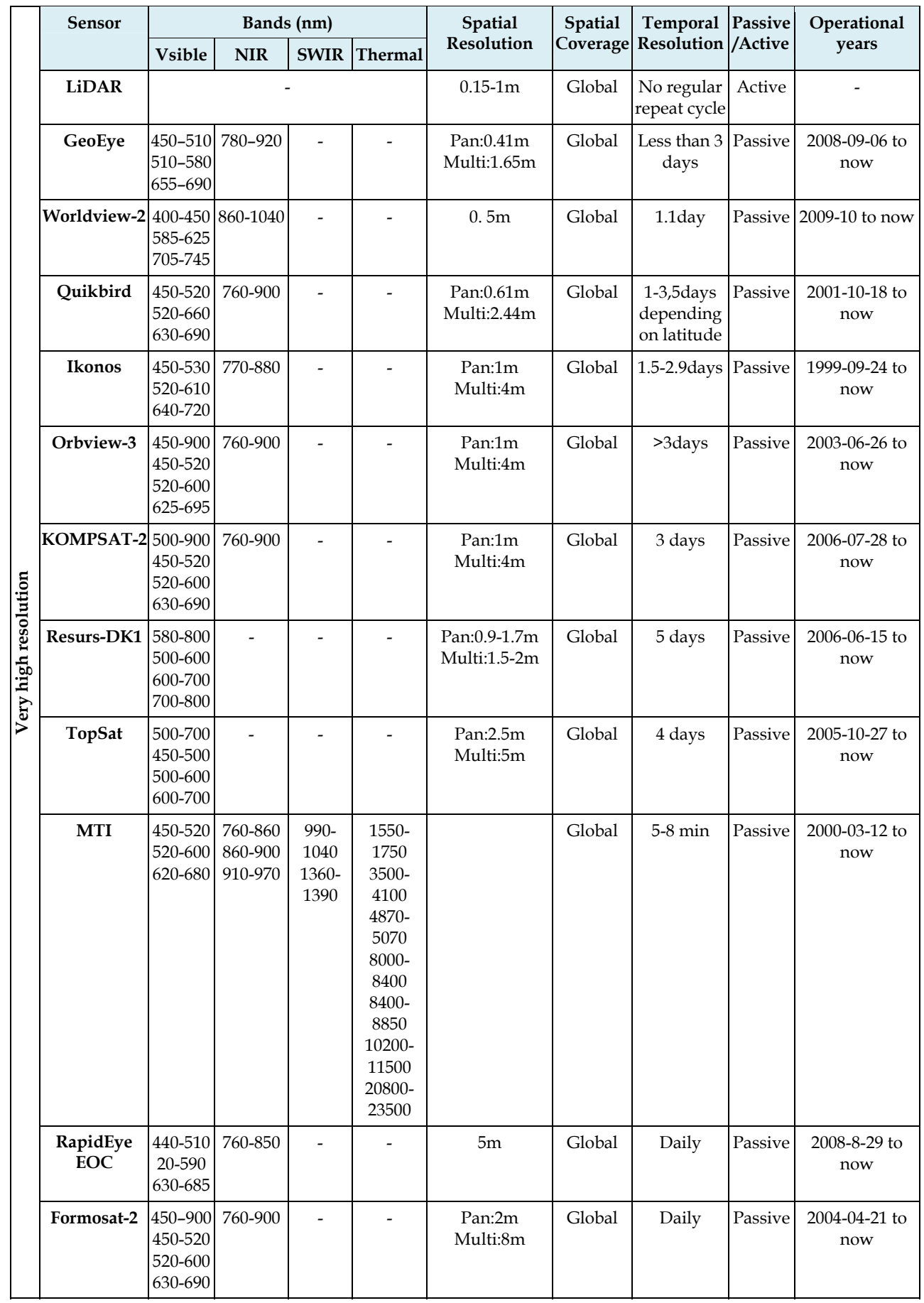




\begin{tabular}{|c|c|c|c|c|c|c|c|c|c|c|}
\hline & \multirow[t]{2}{*}{ Sensor } & \multicolumn{4}{|c|}{ Bands (nm) } & \multirow{2}{*}{$\begin{array}{c}\text { Spatial } \\
\text { Resolution }\end{array}$} & \multirow{2}{*}{$\begin{array}{c}\text { Spatial } \\
\text { Coverage }\end{array}$} & \multirow{2}{*}{$\begin{array}{l}\text { Temporal } \\
\text { Resolution }\end{array}$} & \multirow{2}{*}{$\begin{array}{l}\text { Passive } \\
\text { /Active }\end{array}$} & \multirow{2}{*}{$\begin{array}{c}\text { Operational } \\
\text { years }\end{array}$} \\
\hline & & Vsible & NIR & SWIR & Thermal & & & & & \\
\hline \multirow{12}{*}{ 茕 } & Spot4 & $\begin{array}{c}510-730 \\
500- \\
590 \\
610- \\
680\end{array}$ & $780-890$ & $\begin{array}{l}1580- \\
1750\end{array}$ & - & $\begin{array}{l}\text { Pan:10m } \\
\text { Multi:20m }\end{array}$ & Global & 2-3days & Passive & 1998-03 to now \\
\hline & Spot5 & $\begin{array}{l}490-690 \\
490-610 \\
610-680\end{array}$ & $780-890$ & $\begin{array}{l}1580- \\
1750\end{array}$ & - & $\begin{array}{c}\text { Pan:2.5m,5m } \\
\text { Multi:10m }\end{array}$ & Global & 2-3days & Passive & $\begin{array}{c}2002-05-04 \text { to } \\
\text { now }\end{array}$ \\
\hline & $\begin{array}{c}\text { ALOS } \\
\text { AVNIR-2 }\end{array}$ & $\begin{array}{l}420-500 \\
520-600 \\
610-690\end{array}$ & $760-890$ & - & - & $10 \mathrm{~m}$ & Global & 2days & Passive & $\begin{array}{c}2006-01-24 \text { to } \\
\text { now }\end{array}$ \\
\hline & Terra ASTER & $\begin{array}{l}520-600 \\
630-690\end{array}$ & $760-860$ & $\begin{array}{l}1600- \\
1700\end{array}$ & - & $\begin{array}{l}15 \mathrm{~m} \\
30 \mathrm{~m} \\
90 \mathrm{~m}\end{array}$ & Global & 4-16days & Passive & $\begin{array}{c}1999-12-18 \text { to } \\
\text { now }\end{array}$ \\
\hline & JERS-1 OPS & $\begin{array}{l}520-600 \\
630-690\end{array}$ & $760-876$ & $\begin{array}{c}1600- \\
1710 \\
2010- \\
2120 \\
2030- \\
2250 \\
2270- \\
2400\end{array}$ & - & $18 \mathrm{~m}$ & Global & 44days & Passive & $\begin{array}{c}1992-02-11 \text { to } \\
\text { now }\end{array}$ \\
\hline & $\begin{array}{l}\text { SPOT1- } \\
\text { 3HRV }\end{array}$ & $\begin{array}{l}500-730 \\
500-590 \\
610-680\end{array}$ & $780-890$ & - & - & $\begin{array}{l}\text { Pan:10m } \\
\text { Multi:20m }\end{array}$ & Global & 26days & Passive & $1986-02$ to now \\
\hline & $\begin{array}{l}\text { CBERS } \\
\text { IRMSS }\end{array}$ & $500-900$ & - & $\begin{array}{c}1550- \\
1750 \\
2080- \\
2350 \\
1040- \\
1250\end{array}$ & $\begin{array}{l}10400- \\
12500\end{array}$ & $\begin{array}{l}78 \mathrm{~m}, \\
156 \mathrm{~m}\end{array}$ & Global & 26days & Passive & $\begin{array}{c}\text { 1994-10-14 to } \\
\text { now }\end{array}$ \\
\hline & $\begin{array}{l}\text { Deimos-1/ } \\
\text { UK DMC-2 }\end{array}$ & $\begin{array}{c}520- \\
600 \\
630-690\end{array}$ & $770-900$ & - & - & $22 \mathrm{~m}$ & Global & 3 days & Passive & $\begin{array}{c}2009-07-29 \text { to } \\
\text { now }\end{array}$ \\
\hline & IRS LISS3 & $\begin{array}{c}20-590 \\
620-680\end{array}$ & $770-860$ & $\begin{array}{l}1550- \\
1700 \\
2200- \\
25000\end{array}$ & - & $23 \mathrm{~m}$ & Global & 24days & Passive & $\begin{array}{c}2003-10-17 \text { to } \\
\text { now }\end{array}$ \\
\hline & $\begin{array}{l}\text { Landsat7 } \\
\text { ETM }\end{array}$ & $\begin{array}{l}520-900 \\
450-520 \\
520-600 \\
620-690\end{array}$ & 760-960 & $\begin{array}{l}1550- \\
1750 \\
2080- \\
3350\end{array}$ & $\begin{array}{l}1040- \\
1250\end{array}$ & $\begin{array}{c}\text { Pan: } 15 \mathrm{~m} \\
\text { Muti:30m,60m }\end{array}$ & Global & 16days & Passive & 1999-04 to now \\
\hline & $\begin{array}{l}\text { Landsat4- } \\
\text { 5TM }\end{array}$ & $\begin{array}{l}450-520 \\
520-600 \\
630-690\end{array}$ & $760-900$ & $\begin{array}{c}1550- \\
1750 \\
20800- \\
23500\end{array}$ & $\begin{array}{l}104000- \\
125000\end{array}$ & $30 \mathrm{~m}, 120 \mathrm{~m}$ & Global & 16days & Passive & $\begin{array}{c}1984-03-16 \text { to } \\
\text { now }\end{array}$ \\
\hline & Eo-1 ALI & $\begin{array}{l}520-900 \\
450-520 \\
520-600 \\
620-690\end{array}$ & 760-960 & $\begin{array}{l}1550- \\
1750 \\
2080- \\
3350\end{array}$ & $\begin{array}{l}1040- \\
1250\end{array}$ & $\begin{array}{c}\text { Pan:10m } \\
\text { Muti:30m,60m }\end{array}$ & Global & 16days & Passive & $\begin{array}{c}2000-11-21 \text { to } \\
\text { now }\end{array}$ \\
\hline
\end{tabular}


Coupled Terrestrial Carbon and Water Dynamics in

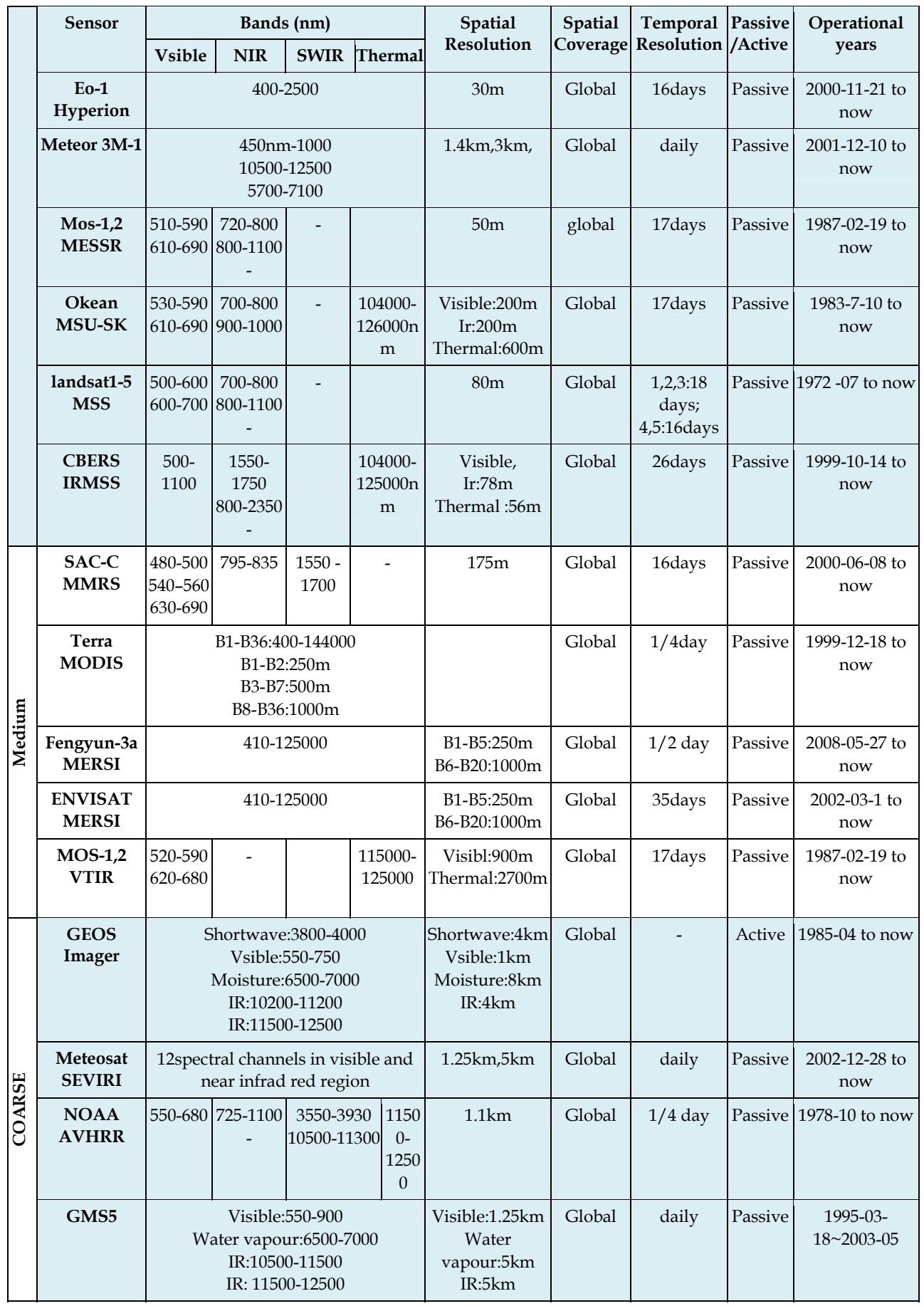




\begin{tabular}{|c|c|c|c|c|c|c|c|c|c|}
\hline \multirow[t]{2}{*}{ Sensor } & \multicolumn{4}{|c|}{ Bands (nm) } & \multirow{2}{*}{$\begin{array}{c}\text { Spatial } \\
\text { Resolution }\end{array}$} & \multirow{2}{*}{$\begin{array}{c}\text { Spatial } \\
\text { Coverage }\end{array}$} & \multirow{2}{*}{$\begin{array}{c}\text { Temporal } \\
\text { Resolution }\end{array}$} & \multirow{2}{*}{$\begin{array}{l}\text { Passive } \\
\text { /Active }\end{array}$} & \multirow{2}{*}{$\begin{array}{c}\text { Operational } \\
\text { years }\end{array}$} \\
\hline & Vsible & NIR & SWIR The & rmal & & & & & \\
\hline GMS1-4 & \multicolumn{4}{|c|}{$\begin{array}{c}\text { Visible:550-900 } \\
\text { Water vapour:6500-7000 } \\
\text { IR:10500-11500 } \\
\text { IR: } 11500-12500\end{array}$} & $\begin{array}{l}\text { Visible: } 1.25 \mathrm{~km} \\
\text { Water } \\
\text { vapour: } 5 \mathrm{~km} \\
\text { IR: } 5 \mathrm{~km}\end{array}$ & Global & daily & Passive & $1997-7$ to now \\
\hline $\begin{array}{l}\text { Fengyun- } \\
\text { 2CD }\end{array}$ & \multicolumn{4}{|c|}{$\begin{array}{c}\text { Visible: } 550-1050 \\
\text { Water vapour:6200-7600 } \\
\text { IR:10500-12500 }\end{array}$} & $\begin{array}{c}\text { Visible: } 1.25 \mathrm{~km} \\
\text { IR: } 5 \mathrm{~km}\end{array}$ & Global & 1 hour & Passive & $\begin{array}{c}\text { C:2004-10-19 } \\
\text { D: } 2006-12--08\end{array}$ \\
\hline $\begin{array}{l}\text { fengYun- } \\
2 A B\end{array}$ & \multicolumn{4}{|c|}{$\begin{array}{c}\text { Visible: } 550-1050 \\
\text { Water vapour:6200-7600 } \\
\text { IR:10500-12500 }\end{array}$} & $\begin{array}{l}\text { Visible: } 1.25 \mathrm{~km} \\
\text { Water } \\
\text { vapour: } 5 \mathrm{~km} \\
\text { IR: } 5 \mathrm{~km}\end{array}$ & Global & 1 hour & Passive & $\begin{array}{l}\text { A:1997-06-10 } \\
\text { B:1997-07-21 }\end{array}$ \\
\hline INSAT-2E & $550-750$ & - & $\begin{array}{l}10500- \\
12500\end{array}$ & - & $\begin{array}{l}\text { Visible: } 2 \mathrm{~km} \\
\text { IR: } 8 \mathrm{~km}\end{array}$ & Global & daily & Passive & $\begin{array}{c}1992-04-02 \text { to } \\
\text { now }\end{array}$ \\
\hline $\begin{array}{l}\text { INSAT-2 } \\
\text { VHRR }\end{array}$ & $550-750$ & - & $\begin{array}{l}10500- \\
12500\end{array}$ & - & $\begin{array}{c}\text { Visible: } 2 \mathrm{~km} \\
\text { IR: } 8 \mathrm{~km}\end{array}$ & Global & daily & Passive & $\begin{array}{c}1995-12-06 \text { to } \\
\text { now }\end{array}$ \\
\hline $\begin{array}{c}\text { Meteosat } \\
\text { MVIRI }\end{array}$ & \multicolumn{4}{|c|}{$\begin{array}{l}\text { Visible: } 450-1000 \\
\text { Water vapour: } 10500-12500 \\
\text { IR: } 5700-7100\end{array}$} & $\begin{array}{c}\text { Visible: } 1.25 \mathrm{~km} \\
\text { Water } \\
\text { vapour: } 5 \mathrm{~km} \\
\text { IR: } 5 \mathrm{~km}\end{array}$ & Global & daily & Passive & $\begin{array}{l}\text { Meteosat- } \\
\text { 7:1993-11 }\end{array}$ \\
\hline
\end{tabular}

Abbreviations: Ali, Advanced land Imager; ALOS AVNIR-2, Advanced Visible and Near Infrared Radiometer type 2; ALOS, Advanced land observing Satellite; ASTER, Japanese Earth Resources Satellite 1; AVHRR, The Advanced Very High Resolution Radiometer; CBERS, The China-Brazil Earth Resources Satellite; Deimos-1, Spanish Earth imaging satellite; DMC, Disaster Monitoring Constellation; Envisat, Environmental Satellite; EOS, Earth Observing System; Etm, Enhanced Thematic Mapper; Formosat-2, the first and only high-resolution satellite; GMS, Geosynchronous Meteorological Satellite; HRV, High Resolution Visible ; INSAT-2E, Indian geostationary communications and weather satellite; KOMPSAT, Korea Multi-Purpose Satellite; IRMSS, Infra-Red Multispectral Scanner; IRMSS, Infrared Multispectral Scanner Camera; IRS, Indian Remote Sensing; LISS-3, Linear Imaging Self-Scanning Sensor - 3. Satellites; Lidar, Light Detection And Ranging; MTI, moving target indication radar; MOS -1, Marine Observation Satellite 1; MESSR, Multi Spectral Electronic Self Scanning Radiometer; MSS, Multispectral Scanner; Meteor 3M-1, Meteorological Satellite; 3M, Monitoring of ocean and land surfaces, Meteorological observations, and Measurement of vertical profiles of aerosol, ozone and other constituents in the atmosphere; MMRS, Multispectral Medium Resolution Scanner; MODIS, The Moderate Resolution Imaging Spectroradiometer; MERSI, Medium Resolution Spectral Imager; MVIRI, METEOSAT Visible and Infrared Imager; NOAA, National Oceanic and Atmospheric Administration; Orbview, the satellite of Orbitally company; OPS, Optical System.

Okean MSU-SK: Multispectral Scanner - Conical Scanning; RapidEyeEOC, Electro-Optical Camera; SEVIRI, Spinning Enhanced Visible Infra-Red Imager; Spot, systeme probatoire d'observation de laterre, TM, Thematic Mapper; Topsat, Tactical Operational Satellite; UK-DMC 2, British Earth imaging satellite, operated by DMC International Imaging; VHRR, Very High Resolution Radiometer; VTIR, Visible and ThermalInfrared Radiometer.

Table 1. Optical Remote Sensing Systems 
Coupled Terrestrial Carbon and Water Dynamics in

\begin{tabular}{|c|c|c|c|c|c|c|c|}
\hline $\begin{array}{c}\text { Spatial } \\
\text { resolution }\end{array}$ & Sensor & Bands & $\begin{array}{c}\text { Spatial } \\
\text { Resolution }\end{array}$ & $\begin{array}{c}\text { Spatial } \\
\text { Coverage }\end{array}$ & $\begin{array}{c}\text { Temporal } \\
\text { Resolution } \\
\end{array}$ & $\begin{array}{l}\text { Passive/ } \\
\text { Active }\end{array}$ & $\begin{array}{c}\text { Operational } \\
\text { years }\end{array}$ \\
\hline \multirow{7}{*}{ 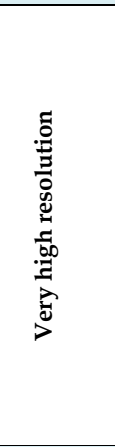 } & Radarsat-2 & $\mathrm{C}$ & $3 \mathrm{~m}$ & Global & 24days & Active & 2007-12-14tonow \\
\hline & Radarsat-1 & $\mathrm{C}$ & \begin{tabular}{|c|}
$10 \mathrm{~m}, 25 \mathrm{~m}, 30 \mathrm{~m}, 35 \mathrm{~m}, 50 \mathrm{~m}$ \\
$100 \mathrm{~m}$
\end{tabular} & Global & 24days & Active & 1995-11-04to now \\
\hline & \multirow[t]{4}{*}{$\begin{array}{l}\text { COSMOS } \\
\text { Skymed }\end{array}$} & \multirow[t]{4}{*}{$\mathrm{X}$} & \multirow[t]{4}{*}{$1 \mathrm{~m}$} & \multirow[t]{4}{*}{ Global } & \multirow[t]{4}{*}{$\begin{array}{c}\text { several } \\
\text { times a day }\end{array}$} & \multirow[t]{4}{*}{ Passive } & $\begin{array}{c}\text { COSMO1:08.06.2007to } \\
\text { now }\end{array}$ \\
\hline & & & & & & & $\begin{array}{c}\text { COSMO2:09.12.2007to } \\
\text { now } \\
\end{array}$ \\
\hline & & & & & & & $\begin{array}{c}\text { COSMO3:25.10.2008to } \\
\text { now } \\
\end{array}$ \\
\hline & & & & & & & $\begin{array}{c}\text { COSMO4:06.11.2010to } \\
\text { now }\end{array}$ \\
\hline & $\begin{array}{c}\text { ALOS } \\
\text { PALSAR }\end{array}$ & $\mathrm{L}$ & $7-100 \mathrm{~m}$ & Global & 2days & Active & 03.01.2002to now \\
\hline \multirow{7}{*}{ 学 } & \multirow[t]{2}{*}{ ERS-1,2 } & \multirow[t]{2}{*}{$\mathrm{C}$} & \multirow[t]{2}{*}{$30 \mathrm{~m}, 50 \mathrm{~km}$} & \multirow[t]{2}{*}{ Global } & \multirow[t]{2}{*}{ 2days } & \multirow[t]{2}{*}{ Active } & ERS-1:03.17.1991to now \\
\hline & & & & & & & ERS-2:04.1995to now \\
\hline & \begin{tabular}{|c|} 
TerraSAR- \\
$\mathrm{X}$ \\
\end{tabular} & $x$ & $1 \mathrm{~m}, 3 \mathrm{~m}, 16 \mathrm{~m}$ & Global & 11days & Active & 06.15.2007to now \\
\hline & 7JERS-1 & $\mathrm{L}$ & $18 \mathrm{mX} 18 \mathrm{~m}$ & Global & 44days & & 02.11.1992 10.12.1998 \\
\hline & $\begin{array}{l}\text { ENVISAT } \\
\text { ASAR }\end{array}$ & $x$ & \begin{tabular}{|c|}
$9 \mathrm{mX6m} ; 30 \times 30 \mathrm{~m} ; 150 \times 15$ \\
$0 \mathrm{~m} ; 450 \mathrm{mX} 450 \mathrm{~m} ; 1800 \mathrm{mX}$ \\
$1800 \mathrm{~m}$
\end{tabular} & Global & 35days & Active & 03.01.2002to now \\
\hline & SIR-C & $\mathrm{X}, \mathrm{C}, \mathrm{L}$ & \begin{tabular}{|c|}
$50 \mathrm{~m}$ \\
$100 \mathrm{~m}$ \\
\end{tabular} & Global & - & Active & $\begin{array}{l}\text { 04.091994 04.12.1999; } \\
\text { 30.091994 11.10.1999; }\end{array}$ \\
\hline & SRTM & $\mathrm{X}, \mathrm{C}$ & $30 \mathrm{mX} 30 \mathrm{~m}$ & $60^{\circ} \mathrm{N} \sim 56^{\circ} \mathrm{S}$ & 16days & Active & $02.11 .2000 \sim 02.10 .2000$ \\
\hline E્: & $\begin{array}{c}\text { Nimbus-7 } \\
\text { SMMR }\end{array}$ & $\mid \begin{array}{c}\mathrm{K}_{\mathrm{a}}, \mathrm{K}, \mathrm{K}_{\mathrm{u}} \\
\mathrm{X}, \mathrm{C}\end{array}$ & $\begin{array}{c}30 \mathrm{~km}, 60 \mathrm{~km}, \\
97.5 \mathrm{~km}, 156 \mathrm{~km}\end{array}$ & Global & 5 6days & Passive & 26.10.1978 08.21.1987 \\
\hline \multirow{10}{*}{ 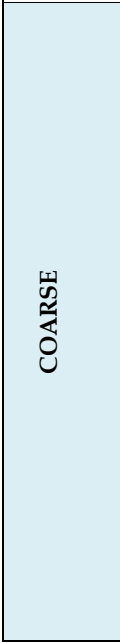 } & TRMM PR & $\mathrm{K}_{\mathrm{u}}$ & $4.3 \sim 5.0 \mathrm{~km}$ & \begin{tabular}{|c|}
$50^{\circ} \mathrm{S} \sim 50^{\circ} \mathrm{N}$ \\
$180^{\circ} \mathrm{W} \sim 180^{\circ} \mathrm{E}$ \\
\end{tabular} & $\begin{array}{l}3 \mathrm{~h}, 1 \mathrm{~d}, \\
3 \mathrm{~d}, 7 \mathrm{~d}\end{array}$ & Active & 12.281997 to now \\
\hline & \begin{tabular}{|c|} 
TRMM \\
TMI \\
\end{tabular} & $\mathrm{K}_{\mathrm{a}, \mathrm{K}}, \mathrm{C}$ & $6 \sim 50 \mathrm{~km}$ & \begin{tabular}{|c|}
$50^{\circ} \mathrm{S} \sim 50^{\circ} \mathrm{N}$ \\
$180^{\circ} \mathrm{W} \sim 180^{\circ} \mathrm{E}$ \\
\end{tabular} & $\begin{array}{l}3 h, 1 d, \\
3 d, 7 d\end{array}$ & Active & 12.28.1997 to now \\
\hline & \begin{tabular}{|c|}
$\begin{array}{c}\text { FengYun 3a } \\
\text { MWRI }\end{array}$ \\
\end{tabular} & $\begin{array}{c}\mathrm{K}_{\mathrm{a}}, \mathrm{K}, \mathrm{K}_{\mathrm{u}} \\
\mathrm{X} \\
\end{array}$ & $250 \mathrm{~m}$ & Global & $5 \mathrm{~d}$ & Passive & 05.27.2008 to now \\
\hline & \begin{tabular}{|c|} 
Aqua \\
AMSR-E \\
\end{tabular} & $\mathrm{K}_{\mathrm{a}, \mathrm{k}, \mathrm{x}}$ & $25 \mathrm{~km}$ & Global & 16day & Passive & $\begin{array}{c}05.04 .2002 \\
\text { To now } \\
\end{array}$ \\
\hline & $\begin{array}{l}\text { DMSP } \\
\text { SSMI } \\
\end{array}$ & $\mathrm{K}_{\mathrm{a}, \mathrm{k}}$ & & Global & $4 \mathrm{~h}$ & Passive & 01.19.1965to now \\
\hline & $\begin{array}{l}\text { DMSP } \\
\text { SSMT }\end{array}$ & $\mathrm{K}_{\mathrm{a}} \mathrm{k}$ & $174 \mathrm{~km}$ & Global & $4 \mathrm{~h}$ & Passive & 01.19.1965to mow \\
\hline & $\begin{array}{c}\text { MOS-1,2 } \\
\text { MSR }\end{array}$ & $\mathrm{K}_{\mathrm{a}, \mathrm{K}}$ & $32 \mathrm{~km}, 23 \mathrm{~km}$ & Global & 17days & Passive & 02.19.1987 04.19.1996 \\
\hline & $\begin{array}{c}\text { ADEOS-1 } \\
\text { NSCAT }\end{array}$ & $\mathrm{K}_{\mathrm{u},}$ & $25 \mathrm{~km}$ & $90 \%$ global sea & 2days & Active & $\begin{array}{c}08.17 .1996 \sim 06.30 .1997 \\
12.2002 \sim 10.24 .2003 \\
\end{array}$ \\
\hline & $\begin{array}{l}\text { SMOS } \\
\text { MIRAS } \\
\end{array}$ & $\mathrm{L}$ & $50 \mathrm{~km}, 200 \mathrm{~km}$ & Global & 16days & Passive & 02.11.2009 to now \\
\hline & CRACE & $\mathrm{K}_{\mathrm{a}, \mathrm{K}}$ & & Global & 16days & Passive & 03.17.2002to now \\
\hline
\end{tabular}

Abbreviations: ADEOS, Advanced Earth Observing Satellite; ALOS, Advanced land observing Satellite; AMSR-E, The Advanced Microwave Scanning Radiometer for EOS; ASAR, An Advanced Synthetic Aperture Radar; COSMO, COnstellation of small Satellites for the Mediterranean basin Observation; DMSP, Defense Meteorological Satellite Program; Envisat, Environmental Satellite; ERS, European Remote-Sensing Satellites; GRACE, Gravity Recovery And Climate Experiment; JERS-1, Japanese Earth 
Resources Satellite 1; MIRAS, Instrument. Synthetic. Apperture Radiometer; MSR, MicrowaveScanning Radiometer; MWR, The Microwave Radiation Imager; NSCAT, NASA SCATterometer; PR, Precipitation Radar; SAR, Synthetic Aperture Rada; SIR-C, Space Imaging Radar; SRTM, Shuttle Radar Topography Mission; SMMR, Scanning Multichannel Microwave Radiometer; SMOS, Soil Moisture and Ocean Salinity; SSMI, Special Sensor Microwave Imager; SSMT, Special Sensor Microwave Temperature; TRMM, Tropical Rainfall Mearsuring Mission; TMI,TRMM's Microwave Imager.

Table 2. Microwave Remote Sensing Systems

Microwave wavelengths penetrate greater depths into plant canopies than optical sensors (Kasischke et al. 1997). The potential for using RADAR (RAdio Detection And Ranging) for studying terrestrial carbon and water cycles, particularly for assessing standing woody biomass is promising. The sensitivity of RADAR to vegetation biomass strongly depends on wavelength: the longer wavelengths, the greater vegetation volumes and biomass levels. Single-band RADAR is able to detect aboveground biomass up to approximately $100 \mathrm{Mg}$ per hectare (Dobson et al. 1992, Luckman et al. 1998). In addition, multiband RADAR enables to separate biomass into component fractions (e.g., stem and canopy) (Saatchi and Moghaddam 2000). Synthetic aperture RADAR (SAR) is also sensitive to vegetation structure and to the amount of biomass, including both photosynthetic (green) and nonphotosynthetic vegetation components (Turner et al., 2004). LiDAR (Light Detection and Ranging) is a remote sensing technology that determines distances to an object or surface using laser pulses, which is a relatively new technology compared to optical sensors, and has the added capability of characterizing the distribution of foliage with height in the canopy (Lefsky et al. 2002, Treuhaft et al. 2002, 2004; Turner et al., 2004). LiDAR data have proved to be highly effective for the determination of three dimensional forest attributes. The suitability of airborne LiDAR for the determination of forest stand attributes including LAI and the probability of canopy gaps within different layers of canopy has been widely acknowledged by various studies (Coops et al., 2004; Coops et al., 2007). The interpreted LiDAR data have been further used for landscape $C$ modeling and scaling (Hilker et al. 2008; Chen et al., 2009). The number and types of sensors used for research on $C$ and water cycles have multiplied many times over since the first sensor launched into orbit. Remote sensing provides consistency of coverage and repeat measurements through time are now indispensable in the $\mathrm{C}$ and hydrological scientist's toolbox.

\subsection{Remote sensing of GPP}

Satellite-based studies have used the light-use efficiency $(\varepsilon)$ approach to estimate GPP (Prince \& Goward, 1995; Running et al., 2000, 2004; Behrenfeld et al., 2001) or net primary production (NPP) (Field et al., 1995; Ruimy et al., 1999). Significant effort and progress have been made in developing the satellite-based GPP algorithms (Running et al., 2004; Xiao et al., 2004; 2005).The algorithm relies on $\varepsilon$ approach relating GPP to the amount of absorbed photosynthetically active radiation (APAR) (Monteith, 1966, 1972), such that,

$$
\mathrm{GPP}=\varepsilon \times f \mathrm{PAR}_{\mathrm{chl}} \times \mathrm{PAR},
$$

where PAR is the photosynetically active radiation (in $\mu$ mol photosynthetic photon flux density, PPFD), $f \mathrm{PAR}_{\mathrm{chl}}$ is the fraction of PAR absorbed by leaf chlorophyll in the canopy, and $\varepsilon$ is the light use efficiency ( $\mu \mathrm{mol} \mathrm{CO}_{2} / \mu \mathrm{mol}$ PPFD). Light use efficiency $(\varepsilon)$ is affected by leaf phenology, temperature, and water: 


$$
\varepsilon=\varepsilon_{0} \times P_{m} \times W_{m} \times T_{m},
$$

where $\varepsilon_{0}$ is the apparent quantum yield or maximum light use efficiency ( $\mu$ mol $\mathrm{CO}_{2} / \mu \mathrm{mol}$ PPFD) for a given land cover type or vegetation function type, and $P_{m}, W_{m}$ and $T_{m}$ are the modifiers for the effects of leaf phenology, water and temperature on light use efficiency of vegetation, respectively.

Different parameters and inputs for the satellite-based algorithm were estimated in different ways: (i) the fraction of PAR absorbed by leaf chlorophyll in the canopy (fPAR $\left.\mathrm{chl}_{\mathrm{cl}}\right)$ and the modifiers $\left(P_{m}, W_{m}\right)$; (ii) PAR and temperature modifier $\left(T_{m}\right)$ were calculated using climate data (either from tower measurements or climate models); and (iii) the maximum light use efficiency $\left(\varepsilon_{0}\right)$ was referred to the land-cover-related look-up table and then modified/optimized using EC tower C measurements and footprint climatology.

To accurately estimate $f \mathrm{PAR}_{\mathrm{chl}}$ in forests is a challenge to both radiative transfer modeling and field measurements. Significant efforts and progress have been made in developing advanced vegetation indices that are optimized for retrieval of fPAR from individual optical sensors (Gobron et al., 1999; Govaerts et al., 1999). The fPAR $\mathrm{Phl}_{\mathrm{c}}$ within the photosynthetically active period of vegetation was estimated as a linear function of the the Enhanced Vegetation Index (EVI),

$$
f \mathrm{PAR}=f(\mathrm{EVI})
$$

EVI is similar in design to NDVI but uses spectral information from the blue band $\left(\rho_{\text {blue }}\right)$. Following Huete et al. (1997) it was computed,

$$
E V I=G \times\left(\rho_{\text {nir }}-\rho_{\text {red }}\right) /\left(\rho_{\text {nir }}+C_{1} \times \rho_{\text {red }}-C_{2} \times \rho_{\text {blue }}+L\right),
$$

where $G=2.5, C_{1}=6, C_{2}=7.5$, and $L=1$. EVI is found to be significantly correlated with the fraction of the photosynthetically active radiation absorbed by leaf chlorophyll in the canopy providing a good surrogate of the spatial variability index for photosynthesis rate.

The parameter $P_{m}$ was estimated using the Normalized Difference Vegetation Index (NDVI) and the Land Surface Water Index (LSWI) and was calculated at two different phases, depending upon life expectancy of leaves (deciduous versus evergreen):

$$
P_{m}=\left\{\begin{array}{rr}
\frac{1+L S W I}{2} & \text { Duirng bud burst to leaf full expansion } \\
1 & \text { After leaf full expansion }
\end{array} .\right.
$$

NDVI (Tucker 1979; Field et al., 1995) was calculated as,

$$
N D V I=\left(\rho_{\text {nir }}-\rho_{\text {red }}\right) /\left(\rho_{\text {nir }}+\rho_{\text {red }}\right),
$$

where $\rho_{\text {nir }}$, and $\rho_{\text {red }}$ are the reflectance in the near infrared and red bands, respectively. NDVI is generally related to green vegetation cover or vegetation canopy density and has been shown to be well correlated with green LAI and biomass (e.g., Sellers, 1985; Myneni et al., 1995).

LSWI (Xiao et al. 2002) is a useful water index and was calculated as the normalized difference between the NIR $(0.78-0.89 \mu \mathrm{m})$ and AWIR $(1.58-1.75 \mu \mathrm{m})$ spectral bands:

$$
L S W I=\left(\rho_{\text {nir }-} \rho_{\text {swir }}\right) /\left(\rho_{\text {nir }+} \rho_{\text {swir }}\right),
$$


where $\rho_{\text {nir }}$ and $\rho_{\text {swir }}$ are the reflectance of near infrared bands, red bands and short infrared bands, respectively.

The timings of bud burst and leaf full expansion can be identified using NDVI. The effect of water on plant photosynthesis $\left(W_{m}\right)$ has been estimated as a function of available soil content in plant root zone and water vapor pressure deficit (VPD) in a number of processbased ecosystem models (e.g. Chen et al., 2007) and remote-sensing based models (e.g. Running et al., 2000). Soil moisture represents water supply to the leaves and canopy, and VPD represents evaporative demand in the atmosphere. Leaf and canopy water content is largely determined by the dynamics of both soil moisture and VPD. As the first order of approximation, here following the alternative and simple approach that uses a satellitederived water index (Xiao et al., 2004), the seasonal dynamics of $W_{m}$ was estimated,

$$
W_{m}=\alpha \times(1+\mathrm{LSWI}) /\left(1+\mathrm{LSWI}_{\max }\right),
$$

where $\alpha$ is a magnifier (its default value equals 1.0) and LSWI $_{\max }$ is the maximum LSWI within the plant growing season for individual pixels. The temperature modifier $T_{m}$ was estimated at each time step, using the equation developed for the terrestrial ecosystem model (Raich et al., 1991),

$$
T_{m}=\frac{\left(\mathrm{T}-\mathrm{T}_{\min }\right)\left(\mathrm{T}-\mathrm{T}_{\max }\right)}{\left[\left(\mathrm{T}-\mathrm{T}_{\min }\right)\left(\mathrm{T}-\mathrm{T}_{\max }\right)\right]-\left(\mathrm{T}-\mathrm{T}_{\mathrm{opt}}\right)^{2}}
$$

where $T_{\min }, T_{\max }$ and $T_{\text {opt }}$ are the minimum, maximum and optimal temperature for photosynthetic activities, respectively. Their default values are respectively set to be 0,35 and $20^{\circ} \mathrm{C}$ in this study. If air temperature falls below $T_{\min }, T_{m}$ is set to be zero.

The $\varepsilon_{0}$ values vary with vegetation types, and the information about $\varepsilon_{0}$ for individual vegetation types can be obtained from a survey of the literature (Ruimy et al., 1995) and optimized using EC tower measurements. According to the work (Zhang et al. 2006), the default $\varepsilon_{0}$ value was estimated to be $0.032 \mu \mathrm{mol} \mathrm{CO} / / \mu \mathrm{mol}$ PPFD in this study stand in 2004 .

\subsection{Remote sensing of ET}

We follow a drop of water traveling through a watershed from input, storage, and finally output and assess how RS can be used to track water fluxes and reservoirs. Table 3 summarizes the potential application of RS to study of hydrology. ET, the largest component of water loss from ecosystems, plays an important role in affecting soil moisture, vegetation productivity, $\mathrm{C}$ cycle, and water budgets in terrestrial ecosystems (Dirmeyer, 1994; Hilker et al. 2008; Chen et al., 2009). In this section, I mainly discuss application of RS to ET.

Verstraeten (Verstraeten et al., 2008) provided a comprehensive review of remote sensing methods for assessing ET and soil moisture content across different scales and Kalma (Kalma et al., 2008) reviewed satellite-based algorithms for estimating ET and land surface temperatures at local, regional and continental scales, with particular emphasis on studies published since the early 1990s. 
In general, water evapotranspired from ecosystems into the atmosphere will reduce the land surface temperature $\left(T_{a}\right)$. Reduction in soil moisture will decrease plant transpiration and evaporation from soil and plant surfaces. Reduction in ET will increase $T_{a}$. $T_{a}$ can be derived from remotely-sensed thermal-infrared (TIR) band (8-14 microns) from various operational satellites. Based on the relationship between $T_{a}$ and ET, remotely sensed $T_{a}$ has been used to estimate regional ET (Gillies et al,. 1997; Kite et al., 2000; Su et al., 2000., Coops et al., 2002). The existing thermal imaging sensors provide adequate coverage of thermal dynamics that are useful for operational monitoring applications of ET. For example, thermal images at 15 minutes intervals and at a spatial resolution of 5 kilometers can be obtained from the NOAA Geostationary Operational Environmental Satellites (GOES), and TIR data at a fine spatial resolution $(60 \mathrm{~m}$ or $120 \mathrm{~m})$ with a much longer time interval (16 days) have been provided by the Thematic Mapper (TM) and ETM+ instruments on Landsat 5 and Landsat 7.

\section{Modeling of $\mathrm{C}$ and water dynamics in terrestrial ecosystems based on remote sensing}

The land surface of the Earth represents significant sources, sinks, and reservoirs of $C$, heat and moisture to the atmosphere. $\mathrm{C}$ and energy fluxes and water cycles at soil-atmosphere and plant-atmosphere interfaces are therefore important land surface processes. Due to the complexity and non-linearity of $\mathrm{C}, \mathrm{N}$ and water dynamics in terrestrial ecosystems, various modeling tools are needed for better understanding of these biogeochemical and hydrological processes and their feedback mechanisms with the land surface climate system (Rannik et al., 2006). The rapidly proliferating volume of spatial data generated by RS has created a significant challenge in terms of designing model algorithms. A spatially distributed processbased model uses spatial data for computing ecohydrological and biophysical processes. The model algorithms represent hypotheses that can be assessed and potentially revised after confrontation with RS and land surface-based observations. It is well known that realistic simulations of $\mathrm{C}$ and water dynamics in terrestrial ecosystems is of critical importance, not only for the surface microclimate, but also for the large-scale physics of the atmosphere (Cox et al., 1999; Gedney et al., 2006; Dickinson et al., 2002). Depending on the scientific objectives or applications, $\mathrm{C}$ and water cycle models have been designed with varying degrees of aggregation with respect to ecosystem processes, components, and RS data as model inputs. Such models can be flagged by land surface, ecosystem and hydrological models based on their objectives and emphases. The former focus on ecosystem processes and the interactions between ecosystems and the atmosphere; while the latter place emphasis on the land surface hydrology processes, including lateral flow resulting from catchment topography.

\subsection{Land surface and ecosystem modeling}

Global climate and the global carbon cycle are controlled by exchanges of water, carbon, and energy between the terrestrial biosphere and atmosphere. Thus land surface models (LSMs) are essential for the purpose of developing predictive capability for the Earth's climate on all time scales (Matthews et al., 1998). Most current LSMs can be associated with three broad types (Seth et al., 1994): soil-vegetation-atmosphere transfer schemes (SVATS), potential vegetation models (PVMs), and terrestrial biogeochemistry models (TBMs).

The first generation of SVATS evolved from simple bucket schemes focusing on soil water availability (Manabe et al., 1969) , through the schemes of Deardorff (Deardorff et al., 1978). 
Marked improvements of the second generation (e.g., BATS (Seth et al., 1994), SiB (Sellers et al., 1997; Sellers et al., 1986), and CLASS (Verseghy et al., 1999; Verseghy et al., 1993) from the first generation are the separation of vegetation from soil and the inclusion of multiple soil layers for dynamic heat and moisture-flow simulations (Chen et al., 2007). The second generation SVATS firstly modeled plant physiology in an explicit manner in GCMs (General Circulation Model or Global Climate Model) (Henderson et al., 1993). For most second-generation SVATS, land cover was fixed, with seasonally-varying prescriptions of parameters such as reflectance, leaf area index or rooting depth (Wang et al., 2002; Kickert et al., 1999; Kley et al., 1999; Schwalm et al., 2001). Some SVATS incorporated satellite data to characterize more realistically the seasonal dynamics in vegetation function (Kickert et al., 1999; Bonan et al., 1994). The latest (third generation) SVATS used more recent theories relating photosynthesis and plant water relations to provide a consistent description of energy exchange, ET, and C exchange by plants (Chen et al., 2007; Sellers et al., 1996). In our effort in understanding the impact of climate change on terrestrial ecosystems, energy, water, and C cycles need to be modelled simultaneously (Sellers et al., 1996; Williams et al., 2001). Recently, most of SVATS have thus been enhanced to include the $\mathrm{CO}_{2}$ flux between the land surface and the atmosphere, such as SiB2 (Sellers, P.J et al, 1996), IBIS (Foley et al., 1996), NCAR-LSM (Bonan et al., 1995), BATS (Dickinson et al., 2002), CLASS-C (Wang et al., 2002) and EASS (Chen et al., 2007).

The earlier generation of PVMs comprised a suite of schemes that focus on modeling distributions of vegetation as a function of climate (Holdridge et al., 1947; Prentice et al., 1990) without influences of anthropogenic or natural disturbance. The second generation of PVMs included more sophisticated modules to account for factors controlling vegetation distributions, such as competition, varying combinations of plant functional types, and physiological and ecological constraints (Prentice et al., 1992).

TBMs developed from scaling up local ecological models, are process-based models that simulate dynamics of energy, water, and carbon and nitrogen exchange among biospheric pools and the atmosphere (Seth et al., 1994). Few of the existing TBMs incorporate PVMs. These models are not applicable to transient climate change experiments without coupling with PVMs.

In recent decades, the interactions among soil, vegetation and climate have been studied intensively and modeled successfully on the basis of water and energy transfer in the soilvegetation-atmosphere system (Seth et al., 1994; Sellers et al., 1986; Verseghy et al., 1999; Verseghy et al., 1993; Zhang et al., 2003). Also the construction and refinement of LSMs have received increasing attention (Sellers et al., 1996; Viterbo et al., 1995; Christopher et al., 2004). Combination of these three different LSMs and utilization of remotely sensed land surface parameters are critical in the future LSM development, because of (1) the tight coupling of exchanges of water, energy and carbon between the land surface and the atmosphere; (2) the sophisticated impact/feedback mechanisms between climate change and terrestrial ecosystems; and (3) increasingly strong anthropogenic alterations to land cover. On-line coupling of a LSM with a GCM is needed for studying interannual to multidecadal climate variations.

Several model intercomparisons have focused on evaluating SVATS and TBMs with particular objectives. For instance, the Project for Intercomparison of Land-surface Parameterization Schemes (PILPS) was initiated to evaluate an array of LSMs existing in GCMs (General Circulation Model or Global Climate Model) (Henderson et al., 1993); while 
the AMMA (African Monsoon Multidisciplinary Analysis) Land Surface Model Intercomparison Project (ALMIP) is being conducted to get a better understanding of the role of soil moisture in land surface processes in West Africa (de Rosnay et al., 2009). Coordinated land surface modeling activities have improved our understanding of land surface processes (de Rosnay et al., 2009).

\subsection{Spatially-distributed hydrological processes modeling}

Hydrology and ecosystem have, for the most part, been studied independently. Most LSMs and ecosystem models make an assumption of "flat Earth" with the absence of lateral redistribution of soil moisture. On the other hand, hydrological models have mostly been concerned with runoff production. Spatially-distributed models are needed, especially for hydrological simulation objective, because of heterogeneity of land surface and non-linearity of hydrological processes. Spatially-distributed hydrological models are not only able to account for spatial variability of hydrological processes, but enable computation of internal fluxes and state variables. Such kinds of models are increasingly applied to simulate spatial variability of forcing variables (e.g. precipitation), physiographic characteristics, detailed processes and internal fluxes within a catchment (Liang et al., 1994; Liang et al., 2004; Beldring et al., 2003; Brath et al., 2004; Christensen et al., 2007; Reed et al., 2004).

\subsection{Modeling dynamics of stable $C$ isotopic exchange between ecosystem and the atmosphere}

It is recognized that the atmospheric measurements are still too sparse, relative to its spatial variability, to be used for inferring the surface flux at high spatial resolution (Ciais et al., 1995). The use of the isotope ratio as an additional constraint to identify various $C$ sources and sinks can contribute to a significant reduction in the uncertainty. Though available isotopic datasets are being accumulated quickly (Griffis et al., 2005; Ponton et al., 2006; Lai et al., 2006; Lai et al., 2005) isotope measurements are still lacking considering land surface diversity and heterogeneity. This shortage of long-term measurements and of sampling frequency still limits $\mathrm{C}$ isotopic studies.

Mechanistic ecosystem models that couple micrometeorological and eco-physiological theories have the potential to shed light on how to extend efforts and applications of stable isotopes of $\mathrm{CO}_{2}$ to global $\mathrm{C}$ budgeting, because biophysical models have the capacities of simulating isotope discrimination in response to environmental perturbations and can produce information on its diurnal, seasonal and interannual dynamics. Few biophysical models, however, have been developed to assess stable $C$ discrimination between a plant canopy and the atmosphere (Suits et al., 2005; Oge'e et al., 2003; Baldocchi et al., 2003). Most existing biophysical models are based on individual leaf level discrimination equations given by Farquhar et al. (Farquhar et al., 1989; Farquhar et al., 1982) and only focus on the land surface layer (ignoring vertical and horizontal advection effects beyond 50 100 m above the ground (Baldocchi et al., 2003). However, in nature, the convective boundary layer (CBL) integrates the effects of photosynthesis, respiration, and turbulent transport of $\mathrm{CO}_{2}$ over the landscape (Lloyd et al., 1996; Pataki et al., 2003). The influence of the CBL cannot be ignored when using isotope composition of $\mathrm{CO}_{2}$ to investigate biological processes (Bowling et al., 1999), because the effect of atmospheric stability on turbulent mixing/diffusion has an important impact on scalar fluxes and concentration fields within 
and above canopies (Baldocchi et al., 1995; Leuning et al., 2000). Few such models considering the CBL effects on isotope fractionation have been developed to date (Lloyd et al.,1996; Lloyd et al., 2001; Chen et al,. 2006; Chen et al., 2006; Chen et al., 2007).

\subsection{Modeling coupled C and water dynamics - An ecohydrological approach}

$\mathrm{C}$ and $\mathrm{N}$ dynamics and hydrological processes are closely linked. The stomatal conductance $\left(g_{\mathrm{s}}\right)$ is the key linkage between $\mathrm{C}$ assimilation (photosynthesis) and transpiration. An empirical equation is used in the second-generation LSMs to calculate $g_{s}$, which is hypothesized to be controlled by the environmental conditions (Jarvis et al., 1976). While field and laboratory studies have documented that leaf photosynthesis also affects $g_{\mathrm{s}}$. Therefore, Ball et al. (Ball et al., 1987) proposed a semi-empirical stomatal conductance formulation (Ball-Woodrow-Berry model), in which $g_{\mathrm{s}}$ is controlled by both photosynthesis and the environmental conditions. Most of third-generation LSMs (Ecological models, e.g. SiB2 (Sellers et al., 1997; Sellers et al., 1996); CN-CLASS (Arain et al., 2006); Ecosys (Grant et al., 2007; Grant et al., 1999; Chen et al., 2007) fully couple photosynthesis and transpiration processes by employing the Ball-Woodrow-Berry stamatal conductance formulation.

In addition to the coupling of hydrological condition and $C$ assimilation through the linkage of $g_{\mathrm{s}}, \mathrm{C}$ assimilation is also coupling with $\mathrm{N}$ dynamics through another biochemical parameter, $V_{c \max }^{25}$--- maximum carboxylation rate at $25{ }^{\circ} \mathrm{C}$. In the photosynthesis model proposed by Farquhar et al. (1980), the net photosynthetic rate $A_{\text {net }}$ at leaf level is a function of two tightly-correlated parameters $V_{c \max }^{25}$ and $J_{c \max }^{25}$ (the maximum electron transport rate at $\left.25^{\circ} \mathrm{C}\right)$, and is calculated as,

$$
A_{\text {net }}=\min \left(A_{c}, A_{j}\right)-R_{d}
$$

where $A_{c}$ and $A_{j}$ are Rubiso-limited and light-limited gross photosynthesis rates, respectively, and $R_{d}$ is the daytime leaf dark respiration and computed as $R_{d}=0.015 V_{c \max }$. $A_{c}$ and $A_{j}$ are expressed as,

$$
A_{c}=V_{c \max } \frac{C_{c}-\Gamma^{*}}{C_{c}+K_{c}\left(1+O_{c} / K_{o}\right)}
$$

and,

$$
A_{j}=J_{\max } \frac{C_{c}-\Gamma^{*}}{4\left(C_{c}+2 \Gamma^{*}\right)}
$$

where $C_{c}$ and $O_{c}$ are the intercellular $\mathrm{CO}_{2}$ and $\mathrm{O}_{2}$ mole fractions (mol mol-1), respectively; $\Gamma^{*}$ is the $\mathrm{CO}_{2}$ compensation point without dark respiration $(\mathrm{mol} \mathrm{mol}-1) ; K_{c}$ and $K_{o}$ are Michaelis-Menten constants for $\mathrm{CO}_{2}$ and $\mathrm{O}_{2}\left(\mathrm{~mol} \mathrm{~mol}^{-1}\right)$, respectively. In the nutrient-limited stands, $A_{\text {net }}$ is generally limited by $A_{c}$, while $A_{c}$ is dominantly controlled by a parameter $V_{c \max }$ (see Eq. 11a). Many research results showed $V_{c \max }^{25}$ is very sensitive to leaf $\mathrm{N}$ status (more specifically leaf Rubisco-N) (Dickinson et al., 2002; Wilson et al., 2000; Wilson et al., 2001; Warren et al., 2001). As a result in some ecosystem models (i.e. C\&N-CLASS (Arain et al., 2006)), $V_{c \max }^{25}$ is calculated as a nonlinear function of Rubisco-N following observations made by Warren and Adams (Dickinson et al., 2002): 


$$
V_{c \max }^{25}(N)=\alpha\left[1-\exp \left(-1.8 N_{r 0}\right]\right.
$$

where $\alpha$ is the maximum value of $V_{c \max }^{25}$ and $N_{r 0}$ is the leaf Rubisco- $\mathrm{N}$ ( $\mathrm{g} \mathrm{N} \mathrm{m}^{-2}$ leaf area) in the top canopy.

The coupled C, N and water processes have been carefully considered in most of the thirdgeneration LSMs (e.g. SiB2 (Sellers et al., 1997; Sellers et al., 1986; Sellers et al., 1996); CNCLASS (Arain et al., 2006) and Ecosys (Grant et al., 2007; Grant et al., 1999), the models' grids, however, are isolated from their neighboring grids mainly due to the availability of input data. Vertical soil hydrological processes are hard to be realistically simulated if the lateral flows are ignored by assuming that the Earth is "flat". However, Simulations of the topographically-driven lateral water flows are important components in most of spatiallydistributed models, while the detailed ecophsiological processes are weakly represented (Govind et al., 2009). Much effort to bridge these two different models has been increasingly made (Rodriguez et al., 2001; D'odorico et al., 2004;Govind et al., 2009; Creed et al., 1998; Band et al., 2001; Porporato et al., 2002; Porporato et al., 2003; Daly et al., 2004; Chen et al., 2005). However, a model coupling approach --- a full combination of ecosystem model and hydrological model, i.e. ecohydrological modeling, is still lacking.

\subsection{Applications of remotely-sensed data in ecohydrological modeling}

Remote sensing techniques, which inherently have the ability to provide spatially comprehensive and temporally repeatable information of the land surface, may be the only feasible way to obtaining data needed for land surface and ecological modeling (Sellers et al., 1986; Gurney et al., 2003; Kite et al., 1996; Engman et al., 1996; Melesse et al., 2008). The most common rationale for interfacing remote sensing and land surface-ecosystem models is using remotely sensed data as model inputs (Plummer et al., 2000). These input data, corresponding to forcing functions or state variables in ecological modeling, include LC, LAI, normalized difference vegetation index (NDVI), and the fraction of photosynthetically active radiation $\left(f_{P A R}\right)$ (Sellers et al., 1986; Running et al., 1998; Chiesi et al., 2002; Loiselle et al., 2001). Another effort is the direct estimation of GPP and net primary productivity (NPP) (Goetz et al., 1999; Seaquist et al., 2003) of biomass (Seaquist et al., 2003; Bergen et al., 1999) and of plant growth (Maas et al., 1988; Kurth et al., 1994), by making use of $f_{P A R}$ and NDVI. It has been shown that the direct estimation has lower accuracy than the integration of remotely sensed data with process based models (Goetz et al., 1999).

Remote sensing data have also been used to parameterize hydrological models (Chen et al., 2005; Kite et al., 1996; Boegh et al., 2004). For instance, a hydrological model (TerrainLab) was further developed using remote sensing as inputs (Chen et al., 2005). TerrainLab is a spatially distributed, process-oriented hydrological model using the explicit routing scheme of Wigmosta et al. (Wigmosta et al., 2004). This model has been applied to flat areas such as boreal and wet land region, (Govind et al., 2009; Chen et al., 2005; Govind et al., 2009), but it has not yet been applied to mountainous areas.

Different from traditional hydrological models, which have coarse spatial resolutions, the grid-based-distributed ecohydrological models have a high demand for spatial data (Kite et al., 1996; Montzka et al., 2008). Some researchers highlight that the main obstacles in current distributed ecohydrological modeling is the lack of sufficient spatially distributed data for 
input and model validation (Stisen et al., 2008). Remote sensing can potentially fill in some of the gaps in data availability and produce means of spatial calibration and validation of distributed hydrological models. As a result the application of remote sensing techniques in hydrological studies and water resources management has progressed in the past decades (see review by (Kite et al., 1996)).

In general, the applications of remotely sensed data in ecohydrological modeling can be in the two ways (Kite et al., 1996; Chen et al., 2005; Boegh et al., 2004; Montzka et al., 2008; Stisen et al., 2008; Ritchie et al., 1996; Schultz et al., 1996; Melesse et al., 2007; Schmugge et al., 2002; Jain et al., 2004; Pietroniro et al., 2005; French et al., 2006): (i) multispectral remote sensing data are used to quantify surface parameters, such as vegetation types and density. Although the usefulness of remote sensing data is widely recognized, there remain few cases where remote sensing data have been actually used in ecohydrological simulations. Difficulties still exist in choosing the most suitable spectral data for studying hydrological processes as well as in interpreting such data to extract useful in formation (Chen et al., 2005; Kite et al., 1996; Engman et al., 1996); and (ii) processed remote sensing data are used to provide fields of hydrological parameters for calibration and validation of ecohydrological models, such as precipitation (Kite et al., 1996; Wang et al., 2001), and soil moisture (Jackson et al., 1993; Hollenbeck et al., 1996., 1996; Kim et al., 2002; Koster et al., 2006). Koster et al. (Koster et al., 2006) pointed out that remote sensing data take the form of emitted and reflected radiances and thus are not the type of data traditionally used to run and calibrate models. Hence, it is important to understand and develop relationships between the electromagnetic signals and hydrological parameters of interest (Chen et al., 2005). Kite and Pietroniro (Kite et al., 1996) stated that the use of remote sensing in hydrological modeling was limited. Even though a number of new sensors have been launched since then and research has documented that remote sensing data have promising perspectives, operational uses of satellite data in hydrological modeling still appear to be in its infancy (Stisen et al., 2008).

\section{Research gaps in $\mathbf{C}$ and water flux estimates and scaling approaches}

A variety of methods are being used in the $C$ and water cycles studies. As shown in Figure 3 , different approaches have different temporal and spatial scales. The most direct measurements of the terrestrial $C$ flux are made either at the plot scale $\left(10^{-2}-10^{1} \mathrm{~m}^{2}\right), e . g$. using biometric methods and various forms of chamber, or at the ecosystem (patch) scale $\left(10^{4}-10^{6} \mathrm{~m}^{2}\right)$, using the EC technique. Ecohydrological / ecosystem modeling and remote sensing estimations are generally available across variable spatiotemporal scales. These estimates are normally available within a nested framework that permits a progressive comparison of measurements made by surface instrumentation (scale: 1 to $10 \mathrm{~m}$ ), surface flux equipment $(10 \mathrm{~m}$ to $1 \mathrm{~km})$, airborne remote sensing equipment (100 $\mathrm{m}$ to several $\mathrm{km}$ ), satellite remote sensing (30 $\mathrm{m}$ to global scale) and EC tower $(1-3 \mathrm{~km})$,

The atmosphere integrates surface fluxes over many temporal and spatial scales and links scalar sources and sinks with concentrations and fluxes. This principle has been successfully used to develop inverse models to estimate annual C budgets (Tans et al., 1990; Enting et al., 1995; Fan et al., 1998; Bousquet et al., 1999; Gurney et al., 2002; Gurney et al., 2003). However, due to model limitations and paucity of continental $\mathrm{CO}_{2}$ observations these 
studies have yielded $\mathrm{C}$ fluxes only at coarse resolution, over large spatial regions (Gurney et al., 2004; Gurney et al., 2005; Gurney et al., 2008).

Progress in $\mathrm{C}$ balance studies has been achieved at both ends of the spatial scale spectrum, either large continents (larger than $10^{6} \mathrm{~km}^{2}$, e.g. global inverse modeling) or small vegetation stands (less than 1-3 $\mathrm{km}^{2}$, e.g. EC-measurements). Methods to estimate $\mathrm{CO}_{2}$ sources and sinks at the intermediate scale (i.e. landscape to regional scales) between continental and local scales are less well advanced. Moreover, the $\mathrm{C}$ cycle in different regions can vary markedly in response to changing climate (Friedlingstein et al., 2003). Reliable estimates of terrestrial $\mathrm{C}$ sources and sinks at landscape to regional spatial scales (finer than those used in global inversions and larger than local EC flux measurements and roughly defined as the range between $10^{2}$ and $10^{6} \mathrm{~km}^{2}$ ) are required to quantitatively account for the large spatial variability in sources and sinks in the near-field of a measurement location (Gerbig et al., 2003), as well as fundamental to improving our understanding of the $\mathrm{C}$ cycle (Crevoisier et al., 2006).

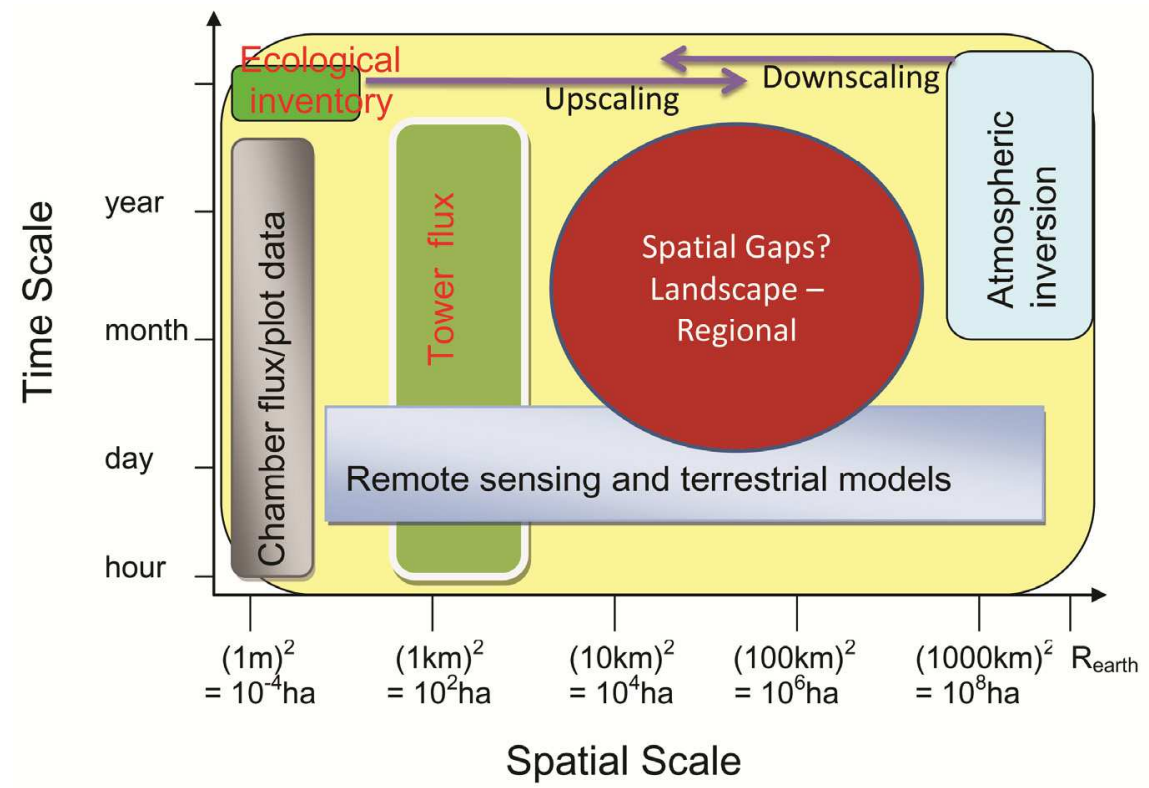

Fig. 3. Temporal and spatial scales of different approaches

It is generally considered unreliable to upscale stand-level fluxes (i.e. EC measurements) to a region by simple spatial extrapolation and interpolation because of the heterogeneity of the land surface and the nonlinearity inherent in ecophysiological processes (Levy et al., 1999). It is also challenging to apply atmospheric inversion technique to regional scales for quantifying annual $\mathrm{C}$ budgets because at such intermediate scales the atmosphere is often poorly constrained (Matross et al., 2006; Gloor et al., 1999). Moreover, aggregation errors and errors in atmospheric transport, both within the PBL and between the PBL and free troposphere, can also be obstacles to using these approaches to obtain quantitative estimates of regional C fluxes (Lin et al., 2004). Hence, there is a strong motivation to develop methods 
to quantify and validate estimates of the $C$ balance at these intermediate scales (Lin et al., 2004; Chen et al., 2008; Bakwin et al., 2004; Matross et al., 2006). Observations of $\mathrm{CO}_{2}$ over the continent within the PBL reflect exchange processes occurring at the surface at a regional scale $\left(10^{2}-10^{5} \mathrm{~km}^{2}\right)$. The flux information contained in $\mathrm{CO}_{2}$ concentration data represents footprints of up to $10^{5} \mathrm{~km}^{2}$ (Gloor et al., 2001; Lin et al., 2004), which are several orders of magnitude larger than the direct EC-flux footprint. This information is therefore needed in our effort to upscale from site to region. Moreover, the number of $\mathrm{CO}_{2}$ mixing ratio measurements above the land surface, made by either tower or aircraft, is steadily increasing. Previous efforts to interpret the signal of regional $\mathrm{CO}_{2}$ exchange making use of tower concentration data have focused on simple one-dimensional PBL budgets that rely on gradients in $\mathrm{CO}_{2}$ concentrations between the PBL and the free troposphere (Bakwin et al., 2004; Helliker et al., 2004). These methods are limited to monthly resolution because of the need to smooth and average over several synoptic events (Matross et al., 2006).

\section{Future research directions}

A synthetic research framework is needed to strength the less well researched areas as reviewed in Section 5: bottom-up and top-down approaches integrating scalable (footprint and ecosystem) models and a spatially nested hierarchy of observations which include multispectral RS, inventories, existing regional clusters of eddy-covariance flux towers and $\mathrm{CO}_{2}$ mixing ratio towers and chambers.

The current research trends and the future directions in this field include: (i) A synthesis aggregation method --- integrating ecohydrological and isotopic models, remote sensing and component flux data, is becoming a pragmatic approach towards a better understanding of the coupled $\mathrm{C}, \mathrm{N}$ and water dynamics at landscape/watershed scales; and (ii) The landscape- and regional-scale $\mathrm{C}$ fluxes are being estimated using an integrated approach involving direct land surface measurements, RS measurements, and ecosystem-, footprint- and inversion- modeling.

\section{Summary}

After comprehensive reviewing of a variety of approaches being used in research on the $\mathrm{C} /$ water cycles, the concluding remarks are summed the following:

Research gaps in this field are (i) The coupled terrestrial $C$ and hydrological dynamics are far from well understood, especially at landscape (watershed) and regional scales; (2) Much progresses have been achieved at the extreme ends of the spatial-scale spectrum, either large regions/continents or small vegetation stands. Because of the heterogeneity of the land surface and the nonlinearity inherent in ecophysiological and ecohydrological processes in response to their driving forces, it is difficult to upscale stand level results to regions and the globe by extrapolation. Budgets of $\mathrm{C}$ and water at landscape intermediate regional scales $\left(10^{2}-10^{5} \mathrm{~km}^{2}\right)$ have large uncertainties.

A coupled spatially-explicit ecohydrological model is a powerful tool for quantitative and predictive understanding of the coupled $C$ and water mechanism. This modeling framework can be used to infer aspects of the land surface system that are difficult to measure, and will be critical to improving the accuracy of forecasts of landscape change and $C$ dynamics in the real world. 
Combining and mutually constraining the bottom-up and top-down methods to reduce their uncertainties using data assimilation techniques is a practical and effective means to derive regional $\mathrm{C}$ and water fluxes with reasonably high accuracy. In the future upscaling framework, spatially nested hierarchy of observations, including multispectral RS, inventories, existing regional clusters of EC flux towers and $\mathrm{CO}_{2}$ mixing ratio towers and chambers, are able to integrated using scalable (footprint and ecosystem and ecohydrological) models and data-model fusion techniques.

\section{Acknowledgements}

This research is financially supported by the National Science Foundation of China (Grant No. 41071059), "One hundred talents" program funded by Chinese Academy of Sciences and Alexander Graham Bell Canada Scholarship (CGS) funded by Natural Sciences and Engineering Research Council of Canada.

\section{References}

Amiro, B.D.; Barr, A.G.; Black, T.A. Carbon, energy and water fluxes at mature disturbed forest sites, Saskatchewan, Canada, Agric. For. Meteor. 2006, 136, 237-251.

Arain, M.A.; Yuan, F.M.; Black, T.A. Soil-Plant Nitrogen Cycling Modulated Carbon Exchanges in a Western Temperate Conifer Forest in Canada. Agric. For. Meteor. 2006, 140, 171-192.

Bakwin, P.S.; Davis, K.J.; Yi, C.; Wofsy, S. C.; Munger, J. W.; Haszpra, L.; Barcza, Z. Regional carbon dioxide fluxes from mixing ratio data. Tellus B 2004, 56, 301-311.

Baldocchi ,D.D.; Falge, E.; Gu, L. et al. FLUXNET: a new tool to study the temporal and spatial variability of ecosystem-scale carbon dioxide, water vapor, and energy flux densities. Bull Amer. Meteorl. Soc. 2001, 82, 2415-2434.

Baldocchi, D.D. Breathing of the terrestrial biosphere: lessons learned from a global network of carbon dioxide flux measurement systems. Aust. J. Bot. 2008, 56, 1-26.

Baldocchi, D.D., Bowling, D.R. Modeling the discrimination of ${ }^{13} \mathrm{C}$ above and within a temperate broad-leaved forest canopy on hourly to seasonal time scales. Plant Cell Environ. 2003, 26, 231-244.

Baldocchi, D.D.; Harley, P.C. Scaling carbon dioxide and water vapour exchange from leaf to canopy in a deciduous forest: model testing and application. Plant, Cell and Environment 1995, 18, 1157-1173.

Baldocchi, D.D.; Wilson, K.B. Modeling $\mathrm{CO}_{2}$ fluxes and water vapor exchange of a temperate broadleaved forest across hourly to decadal time scales. Ecol. Mod. 2001, 142, 155-184.

Ball, J.T.; Woodrow , I.E.; Berry J.A. A model predicting stomatal conductnance amd its contribution to the control of photosynthesis under different environmental conditions, In Progress in Photosynthesis Research, Martinus Nijhoff Publishers: Dordrecht, Netherland, 1987, pp 221-224.

Band, L.E.; Tague, C.L.; Groffman, P.; Belt, K. Forest Ecosystem Processes at the Watershed Scale: Hydrological and Ecological Controls of Nitrogen Export. Hydro. Processes 2001, 15, 2013-2028.

Barford, C. C., Wofsy, S. C., and Goulden, M. L.: Factors controlling long- and short-term sequestration of atmospheric CO2 in a mid-latitude forest. Science, 2001, 294, 16881691. 
Barr, A.G.; Black, T.A.; Hogg, E.H. et al. Inter-annual variability in the leaf area index of a boreal aspen-hazelnut forest in relation to net ecosystem production. Agric. For. Meteor. 2004, 126, 237-255.

Behrenfeld, M. J., Randerson, J. T., McClain, C. R., Feldman, G. C., Los, S. O., and Tucker, C. J.: Biospheric primary production during an ENSO transition, Science, 2001, 291, 2594-2597.

Beldring, S.; Engeland, K.; Roald, L.A.; Sælthun, N.R.; Voksø, A. Estimation of parameters in a distributed precipitation runoff model for Norway. Hydro. Earth System Sci., 2003, 7, 304-316.

Bergen, K.M.; Dobson, M.C. Integration of remotely sensed radar imagery in modeling and mapping forest biomass and net primary production. Ecol. Model. 1999, 122, 257274.

Betts, A.K.; Desjardins, R.L.; Worth D. Impact of agriculture, forest and cloud feedback on the surface energy budget in BOREAS. Agric. For. Meteor. 2007a, 142, 156-169.

Betts, R.A.; Boucher, O.; Collins, M.; Cox, P.M.; Falloon, P.D.; Gedney, N.; Hemming, D.L.; Huntingford, C.; Jones, C.D.; Sexton, D.M.H.; Webb, M.J. Projected Increase in Continental Runoff Due to Plant Responses to Increasing Carbon Dioxide, Nature 2007b, 448, 1037-U5.

Betts, R.A.; Cox, P.M.; Woodward, F.I. Simulated responses of potential vegetation to doubled- $\mathrm{CO}_{2}$ climate change and feedbacks on near-surface temperature, Global Ecol. Biogeogr. 2000, 9, 171-180.

Black, T.A.; Chen, W.J.; Barr, A.G. et al. Increased carbon sequestration by a boreal deciduous forest in years with a warm spring. Geophys. Res. Lett. 2000, 27, 1271-1274.

Blanken, P.D.; Black T.A. The canopy conductance of a boreal aspen forest, Prince Albert national park, Canada. Hydro. Proces. 2004, 18, 1561-1578.

Boegh, E.; Thorsen, M.; Butts, M.B.; Hansen, S.; Christiansen, J.S.; Abrahamsen, P.; Hasager, C.B.; Jensen, N.O.; van der Keur, P.; Refsgaard, J.C.; Schelde, K.; Soegaard, H.; Thomsen, A. Incorporating remote sensing data in physically based distributed agro-hydrological modelling. J. Hydro. 2004, 287, 279-299.

Bonan, G.B. Comparison of two land surface process models using prescribed forcings, $J$. Geophys. Res. 1994, 99, 25,803-25,818.

Bonan, G.B. Land-atmospheric interactions for climate system models: Coupling biophysical, biogeochemical and ecosystem dynamical processes. Remote Sens. Environ. 1995, 51, 57-73.

Bousquet, P.; Ciais, P.; Peylin, P.; Ramonet, M.; Monfray, P. Inverse modeling of annual atmospheric $\mathrm{CO}_{2}$ sources and sinks 1 . method and control inversion. J. Geophys. Res. 1999, 104, 26161-26178.

Bowling, D.R.; Baldocchi, D.D.; Monson, R.K. Dynamics of isotope exchange of carbon dioxide in a Tennessee deciduous forest. Global Biogeochem. Cycles 1999, 13, 903-921.

Brath, A.; Montanari, A.; Toth, E. Analysis of the effects of different scenarios of historical data availability on the calibration of a spatially-distributed hydrological model. $J$. Hydro. 2004, 291, 232-253.

Buermann, W.; Dong, J.; Zeng, X.; Myneni, R.B.; Dickinson, R.E. Evaluation of the utility of satellite-based vegetation leaf area index data for climate simulations, J Clim, 2001, 14, 3536-3550.

Canadell, J. G.; Que' re’, C. Le; Raupacha, M. R.; Fielde, C. B.; Buitenhuisc, E.T.; Ciais, P.; Conwayg, T.J.; Gillettc, N. P.; Houghtonh, R. A.; Marlandi, G. Contributions to 
accelerating atmospheric $\mathrm{CO}_{2}$ growth from economic activity, carbon intensity, and efficiency of natural sinks. PNAS 2007, 104, 18866-18870.

Chen, B.; Black, A.; Coops, N.C.; Hilker, T.; Trofymow, T.; Nesic, Z.; Morgenstern, K. Assessing tower flux footprint climatology and scaling between remotely sensed and eddy covariance measurements. Boundary-Layer Meteorology, 2009a , 130, 137167. DOI: $10.1007 /$ s10546-008-9339-1.

Chen, B.; Black, A.; Coops, N.C.; Jassal, R.; Nesic Z. Seasonal controls on interannual variability in carbon dioxide exchange of a Pacific Northwest Douglas-fir forest, 1997 - 2006, Global Change Biology, 2009b , 15, 1962-1981, doi: 10.1111/j.13652486.2008.01832.x.

Chen, B.; Chen, J. M.; Mo, G.; Yuen, C-W.; Margolis, H.; Higuchi, K.; Chan D. Modeling and scaling coupled energy, water, and carbon fluxes based on remote sensing: An application to Canada's landmass, J. Hydrometeorology, 2007, 8, 123-143,.

Chen, B.; Chen, J.M.; Mo, G.; Black, T.A.; Worthy, D.E.J. Comparison of regional carbon flux estimates from $\mathrm{CO} 2$ concentration measurements and remote sensing based footprint integration. Global Biogeochem Cycles, 2008, 22, GB2012, doi:10.1029/ 2007 GB003024.

Chen, B.; Chen, J.M. Diurnal, seasonal and inter-annual variability of carbon isotope discrimination at the canopy level in response to environmental factors in a boreal forest ecosystem. Plant, Cell and Environment 2007, 30, 1223-1239, doi: 10.1111/j.1365-3040.2007.01707.

Chen, B.; Chen, J.M.; Huang, L.; Tans, P.P. Simulating dynamics of $\delta^{13} \mathrm{C}$ of $\mathrm{CO}_{2}$ in the planetary boundary layer over a boreal forest region: Covariation between surface fluxes and atmospheric mixing. Tellus B 2006, 58,537-549.

Chen, B.; Chen, J.M.; Ju, W. Remote sensing based ecosystem-atmosphere simulation Scheme (EASS) --- model formulation and test with multiple-year data. Ecol. Model. 2007, 209, 277-300.

Chen, B.; Chen, J.M.; Mo, G.; Black, T.A.; Worthy, D.E.J. Comparison of regional carbon flux estimates from $\mathrm{CO}_{2}$ concentration measurements and remote sensing based footprint integration. Global Biogeochem.Cycles, 2008, 22, GB2012, doi:10.1029/ 2007GB003024

Chen, B.; Chen, J.M.; Tans, P.P.; Huang, L. Modeling dynamics of stable carbon isotopic exchange between a boreal ecosystem and the Atmosphere. Global Change Biol. 2006, 12, 1842-1867.

Chen, J.M.; Chen, X.Y.; Ju, W.M.; Geng, X.Y Distributed Hydrological Model for Mapping Evapotranspiration Using Remote Sensing Inputs. J. Hydrol. 2005, 305, 15-39.

Chiesi, M.; Maselli, F.; Bindi, M.; Fibbi, L.; Bonora, L.; Raschi, A.; Tognetti, R.; Cermak, J.; Nadezhdina, N. Calibration and application of FOREST-BGC in a Mediterranean area by the use of conventional and remote sensing data. Ecol. Model. 2002, 154, 251-262.

Christensen, N.; Lettenmaier, D.P. A multimodel ensemble approach to assessment of climate change impacts on the hydrology and water resources of the Colorado River basin. Hydro. Earth System Sci. 2007, 11, 1417-1434.

Christopher, S.R.; Ek, A.R., A process-based model of forest ecosystems driven by meteorology. Ecol. Model. 2004, 179, 317-348.

Ciais, P; Tans P.P.; Trolier, M; White, J.W.C.; Francey, R.J. A large Northern Hemisphere terrestrial $\mathrm{CO}_{2}$ sink indicated by the ${ }^{13} \mathrm{C} /{ }^{12} \mathrm{C}$ ratio of atmospheric $\mathrm{CO}_{2}$. Science 1995 , $269,1098-1102$ 
Coops, N.; Wulder, M.; Culvenor, D.; St-Onge, B. Comparison of forest attributes extracted from fine spatial resolution multispectral and lidar data. Can. J. Remot. Sens. 2004, 30, 855-866.

Coops, N.C.; Black, T.A.; Jassal, R.S.; Trofymow, J.A.; Morgenstern, K. Comparison of MODIS, eddy covariance determined and physiologically modelled gross primary production (GPP) in a Douglas-fir forest stand, Remote Sens Environ, 2007, 107, 385401.

Coops, N.C.; Hilker, T; Wulder, M.A.; St-Onge, B.; Newnham G.; Siggins, A.; Trofymow, J.A. Estimating canopy structure of Douglas-fir forest stands from discrete-return lidar. Trees, 2007, 21, 295-310.

Cosh, M. H.; Brutsaert, W. Microscale structural aspects of vegetation density variability, J. Hydrol., 2003, 276,128-136.

Cox, P.M.; Betts, R.A.; Bunton, C.B.; Essery, R.L.H.; Rowntree, P.R.; Smith, J. The impact of new land surface physics on the GCM simulation of climate and climate sensitivity. Climate Dyn. 1999, 15, 183-203.

Cox, P.M.; Betts, R.A.; Jones, C.D.; Spall, S.A.; Totterdell, I.J. Acceleration of Global Warming Due to Carbon-Cycle Feedbacks in a Coupled Climate Model. Nature 2000, 408, 184.

Creed, I.F.; Band, L.E. Exploring Functional Similarity in the Export of Nitrate-N From Forested Catchments: a Mechanistic Modeling Approach. Water Resour. Res., 1998, 34, 3079- 3093.

Crevoisier, C.; Gloor, M.; Gloaguen, E.; Horowitz, L.W.; Sarmiento, J.; Sweeney, C.; Tans, P. A direct carbon budgeting approach to infer carbon sources and sinks: Design and synthetic application to complement the NACP observation network. Tellus B, 2006, 58, 366-375.

Daly, E.; Porporato, A.; Rodriguez-Iturbe, I. Coupled Dynamics of Photosynthesis, Transpiration, and Soil Water Balance. Part I: Upscaling From Hourly to Daily Level. J. Hydrometeo. 2004, 5, 546-558.

De Rosnay, P.; Drusch, M.; Boone, A.; Balsamo, G.; Decharme, B.; Harris, P.; Kerr, Y.; Pellarin, T.; Polcher, J.; Wigneron J.-P. AMMA Land Surface Model Intercomparison Experiment coupled to the Community Microwave Emission Model: ALMIP-MEM, J. Geophys. Res., 2009, 114, D05108, doi:10.1029/ 2008JD010724.

Deardorff, J.W. Efficient prediction of ground surface temperature and moisture, with inclusion of a layer of vegetation. J. Geophys. Res., 1978, 83, 1889-1903.

Dickinson, R.E.; Berry, J.A.; Bonan, G.B. et al. Nitrogen controls on climate model evapotranspiration. J. Climat. 2002, 15, 278-295.

Diego, S.; Peylin, P.; Viovy, N.; Ciais, P. Optimizing a process-based model with eddycovariance flux measurements: A pine forest in southern France. Global Biogeochemical cycles, 2007, 21, GB2013, doi:1029/2006GB002834.

Dirmeyer, P.A. Vegetation stress as a feedback mechanism in mid-latitude drought. $J$. Climate, 1994, 7, 1463-1483.

Dobson, M.C.; Ulaby, F.T.; Le Toan, T.; Beaudoin, A.; Kasischke, E.S.; Christensen, N.: Dependence of radar backscatter on coniferous forest biomass. IEEE Transactions on Geoscience and Remote Sensing, 1992, 30, 412-415.

D'odorico, P.; Porporato, A.; Laio, F.; Ridolfi, L.; Rodriguez-Iturbe, I. Probabilistic Modeling of Nitrogen and Carbon Dynamics in Water-Limited Ecosystems. Ecol. Model. 2004, 179, 205-219. 
Drolet, G.G.; Middleton, E.M.; Huemmrich, K.F.; Hall, F.G.; Amiro, B.D.; Barr, A.G. Regional mapping of gross light-use efficiency using MODIS spectral indices, Remote., Sens. Environ., 2008, 112, 3064-3078.

Efron, B.; Tibshirani, R. J. An Introduction to the Bootstrap. Chapman \& Hall/CRC, Boca Raton, 1993.

Engman, E.T. Remote sensing applications to hydrology: future impact. Hydro. Sci. J. 1996, 41, 637-647.

Enting, I.G.; Trudinger, C.M.; Francey, R.J. A synthesis inversion of the concentration and $\delta^{13} \mathrm{C}$ of atmospheric $\mathrm{CO}_{2}$. Tellus B 1995, 47, 35-52.

Falge, E.; Baldocchi, D.; Olson, R. et al. Gap filling strategies for defensible annual sums of net ecosystem exchange, Agric. For. Meteorol., 2001, 107, 43-69.

Falk, M.; Wharton, S.; Schroeder, M. et al. Flux partitioning in an old-growth forest: seasonal and interannual dynamics. Tree Physiol. 2008, 28, 509-520.

Fan, S.; Gloor, M.; Mahlman, J.; Pacala, S.; Sarmiento, J. et al. A large terrestrial carbon sink in North America implied by atmospheric and oceanic carbon dioxide data and models. Science 1998, 282, 442-446.

Farquhar, G.D.; Ehleringer, J.R.; Hubick, K.T. Carbon isotope discrimination and photosynthesis. Annual Review of Plant Physiology and Plant Molecular Biol. 1989, 40, 503-537.

Farquhar, G.D.; O'Leary, M.H.; Berry, J.A. On the relationship between carbon isotope discrimination and the intercellular carbon dioxide concentration in leaves. Aust. J. Plant Physi. 1982, 9, 121-137.

Field, C. B.; Randerson, J. T.; Malmstrom, C. M. Global net primary production-combining ecology and remote sensing. Remote Sensing of Environment, 1995, 51, 74-88,

Finnigan, J. The footprint concept in complex terrain, Agric For Meteorol., 2004,127,117-129,.

Foken, T., Leclerc, M.Y.: Methods and limitations in validation of footprint models. Agricultural and Forest Meteorology, 2004, 127, 223-234.

Foley, J.A.; Prentice, I.C.; Ramankutty, N.; Levis, S.; Pollard, D.; Sitch, S.; Haxeltine, A.; An integrated biosphere model of land surface processes, terrestrial carbon balance, and vegetation dynamics. Global Biogeochem. Cycles 1996, 10, 603-628.

French, R.H.; Miller, J.J.; Dettling, C.; Carr, J. Use of remotely sensed data to estimate the flow of water to a playa lake. J. Hydro.2006, 325, 67-81.

Friedlingstein, P.; Dufresne, J.L.; Cox, P.M.; Rayner, P. How Positive Is the Feedback Between Climate Change and the Carbon Cycle? Tellus B 2003, 55, 692-700.

Gao, F., Masek, J., Schwaller,M., and Hall, H: On the blending of the Landsat andMODIS surface reflectance: Predicting daily Landsat surface reflectance. IEEE Transactions on Geosciences and Remote Sensing, 2006, 44, 2207-2218,.

Gedney, N.; Cox, P.M.; Betts, R.A.; Boucher, O.; Huntingford, C.; Stott, P.A. Detection of a Direct Carbon Dioxide Effect in Continental River Runoff Records. Nature, 2006, 439, 835-838.

Gerbig, C.; Lin, J. ; Wofsy, S.C.; Daube, B.C.; Andrews, A.E., et al. Towards constraining regional scale fluxes of $\mathrm{CO}_{2}$ with atmospheric observations over a continent: 1 . Observed spatial variability from airborne platforms. J. Geophys. Res. 2003, 108, D4756,10.1029/2002JD003018.

Gillies, R.R.; Cui, J.; Carlson, T.N.; Kustas, W.P.; Humes, K.S. Verification of a method for obtaining surface soil water content and energy fluxes from remote measurements of NDVI and surface radiant temperature. Inter. J. Remot. Sens., 1997, 18, 3145-3166. 
Gloor, M.; Bakwin, P.; Hurst, D.; Lock, L.; Draxler, R.; Tans, P. What is the concentration footprint of a tall tower? J. Geophys. Res. 2001, 106, 17,831-17,840.

Gloor, M.; Fan, S.M.; Pacala, S.; Sarmiento, J.; Ramonet, M. A model-based evaluation of inversions of atmospheric transport, using annual mean mixing ratios, as a tool to monitor fluxes of nonreactive trace substances like $\mathrm{CO}_{2}$ on a continental scale. $J$. Geophys. Res. 1999, 104, 14245-14260.

Gobron, N.; Pinty, B.; Verstraete, M.; Govaerts, Y. The MERIS Global Vegetation Index (MGVI): Description and preliminary application, International Journal of Remote Sensing, 1999, 20, 1917- 1927.

Goetz, S.J.; Prince, S.D.; Goward, S.N.; Thawley, M.M.; Small, J. Satellite remote sensing of primary production: an improved production efficiency modelling approach. Ecol. Model. 1999, 122, 239-255.

Gökede, M.; Rebmann, C.; Foken, T. A combination of quality assessment tools for eddy covariance measurements with footprint modelling for the characterisation of complex sites, Agric. For. Meteorol., 2004,127, 175-188.

Govaerts, Y. M.; Verstraete, M. M.; Pinty, B.; Gobron, N. Designing optimal spectral indices: A feasibility and proof of concept study, International Journal of Remote Sensing, 1999, 20, 1853- 1873.

Govind, A.; Chen, J. M.; Ju, W. Spatially explicit simulation of hydrologically controlled carbon and nitrogen cycles and associated feedback mechanisms in a boreal ecosystem, J. Geophys. Res., 2009, 114, G02006, doi:10.1029/2008JG000728.

Govind, A.; Chen, J.M.; Margolis, H.; Ju, W.; Sonnentag, O.; Giasson, M.-A. A spatially explicit hydro-ecological modeling framework (BEPS-TerrainLab V2.0): Model description and test in a boreal ecosystem in Eastern North America. J. Hydro.. 2009, 367, 200-216.

Grant, R.F.; Black, T.A.; den Hartog, G. et al. Diurnal and annual exchanges of mass and energy between an aspen-hazelnut forest and the atmosphere: testing the mathematical model Ecosys with data from the BOREAS experiment. J. Geophys. Res. 1999, 27, 27699-27718.

Grant, R.F; Flanagan, L.B. Modeling stomatal and nonstomatal effects of water deficits on CO2 fixation in a semiarid grassland. J. Geophys. Res. 2007, 112, G03011, doi:10.1029/2006JG000302.

Griffis, T. J.; Black, T. A.; Morgenstern , K. Ecophysiological controls on the carbon balances of three southern boreal forests. Agricultural and Forest Meteorology, 2003, 117, 5371.

Griffis, T.J.; Baker, J.M.; Zhang, J. Seasonal dynamics and partitioning of isotopic $\mathrm{CO}_{2}$ exchange in $\mathrm{C}_{3} / \mathrm{C}_{4}$ managed ecosystem. Agric. For. Meteor. 2005, 132, 1-19.

Gurney, K. R. et al. TransCom $3 \mathrm{CO}_{2}$ Inversion Intercomparison: 1. Annual mean control results and sensitivity to transport and prior flux information. Tellus B 2003, 55, 555- 579 .

Gurney, K.R.; Law, R.M.; Denning, A.S.; Rayner, P.J.; Baker, D. et al. Towards robust regional estimates of $\mathrm{CO}_{2}$ sources and sinks using atmospheric transport models. Nature 2002, 415, 626-630.

Hall, F. G.; Hilker, T.; Coops, N. C.; Lyapustin, A.; Huemmrich, F.; Middleton, E.; Margolis, H.; Drolet, G.; Black, T. Multi-angle remote sensing of forest light use efficiency by observing PRI variation with canopy shadow fraction. Remote Sensing of Environment. , 2008, 112:3201-3211. 
Hall, F.; Sellers, P.; Strebel, D.; Kanemasu, E.; Kelly, R.; Blad, B.; Markham, B.; Wang, J.; Huemmrich, F. Satellite remote sensing of surface energy and mass balance results: Results from FIFE. Remote Sensing of Environment, 1991, 35, 187-199.

Harris, P. P.; Huntingford, C.; Cox, P. M.; Gash, J. H.C.; Malhi, Y. Effect of soil moisture on canopy conductance of Amazonian rainforest. Agric. For. Meteor. 2004, 122, 215-227.

Hedges, J.I. Global biogeochemical cycles: progress and problems. Mar. Chem., 1992. 39, 6793.

Helliker, B.R.; Berry, J.A.; Betts, A.K.; Bakwin, P.S.; Davis, K.J.; Denning, A.S.; Ehleringer, J. R.; Miller, J.B.; Butler, M.P.; Ricciuto D.M. Estimates of net $\mathrm{CO}_{2}$ flux by application of equilibrium boundary layer concepts to $\mathrm{CO}_{2}$ and water vapor measurements from a tall tower. J. Geophys. Res. 2004, 109, D20106, doi:10.1029/2004JD004532.

Henderson-Sellers, A.; Yang, Z.-L.; Dickinson, R.E. The Project for Intercomparison of Landsurface Parameterization Schemes, Bull. Amer. Meteorol. Soc., 1993, 74, 1335.

Hilker, T.; Coops, N.C.; Hall, F.G.; Black, T.A.; Chen, B.; Krishnan, P.; Wulder, M.A.; Sellers, P.J.; Middleton, E.M.; Huemmrich, K.F. A modeling approach for upscaling gross ecosystem production to the landscape scale using remote sensing data. J. Geophys Res.,2008 113, G03006, doi:10.1029/2007JG000666.

Holdridge, L. Determination of world plant formations from simple climatic data, Science 1947,105, 367-368.

Hollenbeck, K.J.; Schmugge, T.J.; Homberger, G.M.; Wang, J.R. Identifying soil hydraulic heterogeneity by detection of relative change in passive microwave remote sensing observations. Water Resour. Res. 1996, 32, 139-148.

Hollinger, D. Y.; Goltz, S.M.; Davidson, E. A. Seasonal patterns and environmental control of carbon dioxide and water vapour exchange in an ecotonal boreal forest. Global Change Biology, 1999, 5, 891-902.

Hollinger, D. Y.; Richardson, A. D. Uncertainty in eddy covariance measurements and its application to physiological models. Tree Physiology, 2005, 25, 873-885.

Horst, T.W.; Weil, J.C. Footprint estimation for scalar flux measurements in the atmospheric surface layer. Boundary-Layer Meteorol., 1992, 59, 279-296.

Huang, M.; Ji, J.; LI, K.; Liu, Y.; Yang, F.; Tao, B. The ecosystem carbon accumulation after conversion of grasslands to pine plantations in subtropical red soil of South China, Tellus, 2007, 59B, 439-448.

Huete, A. R.; Liu, H. Q.; Batchily, K.; vanLeeuwen, W. A comparison of vegetation indices over a global set of TM images for EOS-MODIS, Remote Sensing of Environment, 1997, 59, 440-451.

Huete, A.; Didan, K.; Miura, T.; Rodriguez, E. P.; Gao, X.; Ferreira, L. G. Overview of the radiometric and biophysical performance of the MODIS vegetation indices, Remote Sensing of Environment, 2002, 83, 195- 213.

Jackson, T.J. Measuring surface soil moisture using passive microwave remote sensing. Hydro. Processes 1993, 7, 139-152.

Jain, M.K.; Kothyari, U.C.; Raju K.G. A GIS based distributed rainfall-runoff model. J. Hydro.2004, 299, 107-135.

Jarvis, P.G. Interpretation of variations in leaf water potential and stomatal conductance found in canopies in field. Philos Trans R Soc Lond B Biol Sci, 1976, 273, 593-610.

Joos, F.; Prentice, I.C.; Sitch, S.; Meyer, R.; Hooss, G.; Plattner, G.K.; Gerber, S.; Hasselmann, K. Global Warming Feedbacks on Terrestrial Carbon Uptake under the 
Intergovernmental Panel on Climate Change (Ipcc) Emission Scenarios, Global Biogeochem. Cycles, 2001, 15, 891-907.

Ju, J.C.; Roy, D.P. The availability of cloud-free Landsat ETM+ data over the conterminous United States and globally. Remote Sensing of the Environment, 2007 112, 1196-1211.

Kalma, J. D.; McVicar, T. R.; McCabe, M. F. Estimating Land Surface Evaporation: A Review of Methods Using Remotely Sensed Surface Temperature Data, Surv. Geophys., 2008, 29, 421-469.

Kalvelage, T.; Willems, J. Supporting users through integrated retrieval, processing, and distribution systems at the Land Processes Distributed Active Archive Center. Acta Astronautica, 2005, 56, 681-687.

Kasischke, E.S.; Melack, J.M.; Dobson, M.C. The use of imaging radars for ecological applications - a review. Remote Sensing of Environment, 1997, 59, 141-156

Kickert, R.N.; Tonella, G.; Simonov, A.; Krupa, S. Predictive modeling of effects under global change. Environ. Pollut. 1999, 100, 87-132.

Kim, G.; Barros, A.P. Space-time characterization of soil moisture from passive microwave remotely sensed imagery and ancillary data. Remote Sens. Environ. 2002, 81, 393 403.

Kite, G.W.; Pietroniro, A. Remote sensing applications in hydrological modelling. Hydro. Sci. J. 1996, 41, 563-591.

Kite, G.W.; Droogers, P. Comparing evapotranspiration estimates from satellites, hydrological models and field data. J. Hydrol. 2000, 229, 3-18.

Kley, D.; Kleinmann, M.; Sandermann, H.; Krupa, S. Photochemical oxidants: state of the science. Environ. Pollut. 1999, 100, 19-42.

Kljun, N.; Kormann, R.; Rotach, M.W. Comparison of the Langrangian footprint model LPDM-B with an analytical footprint model. Boundary-Layer Meteorology , 2003, 106, 349-355.

Koster, R.D.; Guo, Z.C.; Dirmeyer, P.A.; Bonan, G.;Chan, E.; Cox, P.; Davies, H.; Gordon, C.T.; Kanae, S.; Kowalczyk, E., et al. Glace: the Global Land-Atmosphere Coupling Experiment. Part I: Overview. J. Hydrometeor. 2006, 7, 590-610.

Kurth, W. Morphological models of plant growth: possibilities and ecological relevance. Ecol. Model. 1994, 75, 299-308

Lai C.T.; Ehleringer, J.; Schauer, A.; Tans , P.P.; Hollinger, D.; Paw, K.T.U.; Munger, J.; Wofsy, S. Canopy-scale $\delta^{13} \mathrm{C}$ of photosynthetic and respiratory $\mathrm{CO}_{2}$ fluxes: observations in forest biomes across the United States. Global Change Biol. 2005, 11, 633-643, doi: 10.1111/j.1365-2486.2005.00931.x.

Lai, C.-T.; Schauer, A.J.; Owensby, C. et al. Regional $\mathrm{CO}_{2}$ fluxes inferred from mixing ratio measurements: estimates from flask air samples in central Kansas, USA. Tellus $B$ 2006, 58, 523-536.

Law, B. E.; Waring, R. H.; Anthoni, P. M. Measurements of gross and net ecosystem, productivity and water vapour exchange of a Pinus ponderosa ecosystem, and evaluation of two generalized models, Global Change Biol., 2000, 6, 155-168.

Law, B.E.; Falge, E; Gu, L. et al. Environmental controls over carbon dioxide and water vapor exchange of terrestrial vegetation. Agric. For. Meteor. 2002, 113, 97-120.

Lee, X.; Fuentes, J. D.; Staebler, R. M. Long-term observation of the atmospheric exchange of CO2 with a temperature deciduous forest. Journal of Geophysical Research, 1999, 104, 15975-15984. 
Lefsky, M.A.; Cohen, W.B.; Parker, G.G.; Harding, D.J. Lidar remote sensing for ecosystem studies. BioScience, 2002, 52, 19-30.

Leuning, R. Estimation of scalar source/sink distributions in plant canopies using Lagrangian dispersion analysis: Corrections for atmospheric stability and comparison with a multilayer canopy model. Boundary-Layer Meteor. 2000, 96, 293314.

Levin, S.A. Complex adaptive systems: exploring the known, unknown and unknowable. Bull. Amer. Meteor. Soc. 2002, 40, 1-19.

Levis, S.; Foley, J.A.; Pollard D. Potential high-latitude vegetation feedbacks on $\mathrm{CO}_{2}$-induced climate change, Geophys. Res. Lett, 1999, 26, 747-750.

Levy, P. E.; Grelle, A.; Lindroth, A. et al. Regional-scale CO2 fluxes over central Sweden by a boundary layer budget method. Agric. For. Meteor. 1999, 98-99, 169-180.

Li, Z.; Yu, G.; Xiao, X. et al. Modeling gross primary production of alpine ecosystems in the Tibetan Plateau using MODIS images and climate data, Remote Sensing of Environment, 2007, 107, 510-519.

Liang, X.; Guo, J.; Leung, L.R. Assessment of the effects of spatial resolutions on daily water flux simulations. J. Hydrol. 2004, 298, 287-310.

Liang, X.; Lettenmaier, D.P.; Wood, E.F.; Burges, S.J. A simple hydrologically based model of land surface water and energy fluxes for GSMs. J. Geophys. Res., 1994, 99, 1441514428 .

Lin, J.C.; Gerbig, C.; Wofsy, S.C.; Andrews, A.E.; Daube, B.C.; Grainger, C.A. Stephens, B.B., Bakwin, P.S.; Hollinger D.Y. Measuring fluxes of trace gases at regional scales by Lagrangian observations: Application to the $\mathrm{CO}_{2}$ Budget and Rectification Airborne (COBRA) study, J. Geophys. Res. 2004, 109, D15304, doi:10.1029/2004JD004754.

Liu, Y., Yu, G., Wen, X., Wang, Y., Song, X, Li, J., Sun, X., Yang, F., Chen, Y., Liu Q.: Seasonal dynamics of $\mathrm{CO} 2$ fluxes from subtropical plantation coniferous ecosystem. Science in China Series D, 2006, 49 Supp.II, 99-109.

Lloyd, J.; Francey, R.J.; Mollicone, D. et al. Vertical profiles, boundary layer budgets, and regional flux estimates for $\mathrm{CO}_{2}$ and its ${ }^{13} \mathrm{C} /{ }^{12} \mathrm{C}$ ratio and for water vapor above a forest/bog mosaic in central Siberia. Global Biogeochem. Cycles 2001, 15, 267-284.

Lloyd, J.; Kruijt, B.; Hollinger, D.Y., et al. Vegetation effects on the isotopic composition of atmospheric $\mathrm{CO}_{2}$ at local and regional scales: theoretical aspects and a comparison between rain forest in Amazonia and a boreal forest in Siberia. Austr. J. Plant Physi. 1996, 23, 371-399.

Loiselle, S.; Bracchini, L.; Bonechi, C.; Rossi, C. Modelling energy fluxes in remote wetland ecosystems with the help of remote sensing. Ecol. Model. 2001, 145, 243-261.

Luckman, A.; Baker, J.; Honzak, M.; Lucas, R. Tropical forest biomass density estimation using JERS-1 SAR: Seasonal variation, confidence limits and application to image mosaics. Remote Sensing of Environment, 1998, 63, 126-139.

Ma, S.; Baldocchi, D.D.; Xu, L. et al. Interannual variability in carbon dioxide exchage of an oak/grass sacanna and open grassland in California. Agric. For. Meteor. 2007, $147,157-171$

Maas, S.J. Use of remotely sensed information in agricultural crop growth models. Ecol. Model. 1988, 41, 247-268.

Marquis, M.; Tans, P. Carbon Crucible, Science, 2008, 320, 460-470.

Matthews, E.; Hansen, J. Eds. Land Surface Modeling: A Mini-Workshop, May 1998: http://www.giss.nasa.gov/meetings/landsurface1998/section3.html 
Melesse A.M.; Vijay N.; Jon H. Analysis of Energy Fluxes and Land Surface Parameters in Grassland Ecosystem: Remote Sensing Perspective. Int. J. Remot. Sens. 2008, 29, 3325-3341.

Melesse, A.M.; Weng, Q.; Thenkabail, P.; Senay, G. Remote sensing sensors and applications in environmental resources mapping and modeling. Sensors 2007, 7, 3209-3241

Meybeck, M. Carbon, nitrogen, and phosphorous transport by world rivers. Am. J. Sci. 1982, 282, 401-450.

Monteith, J. L. Solar radiation and productivity in tropical ecosystems, J. of Applied Ecology, $1972,9,747-766$.

Monteith, J. L. The photosynthesis and transpiration of crops, Experimental Agriculture, 1966, 2, 1-14.

Montzka, C.; Canty, M.; Kunkel, R.; Menz, G.; Vereecken, H.; Wendland F. Modelling the water balance of a mesoscale catchment basin using remotely sensed land cover data. J. Hydro. 2008, 353, 322-334.

Natl. Res. Counc. Earth Observations from Space: The First 50 Years of Scientific Achievements. 2008, Washington, DC: Natl. Acad. Press. 142 pp.

Oge'e, J.; Brunet, Y.; Loustau, D.; Berbigier, P.; Delzon, S. MuSICA, a $\mathrm{CO}_{2}$, water and energy multi-layer, multi-leaf pine forest model: Evaluation from hourly to yearly time scales and sensitivity analysis. Global Change Biol. 2003, 9, 697-717.

Papale, D.; Valentini, R. A new assesment of European forests carbon exchanges by eddy fluxes and artificial neural network spatialization. Global Change Biology, 2003, 9, 525-535.

Parton, W.J.; Ojima, D.S.; Cole, C.V.; Schimel, D.S. A general model for soil organic matter dynamics: sensitivity to litter chemistry, texture and management. Soil Sci. Soc. Am. J. 1993, 39, 147167.

Pataki, D.E.; Ehleringer, J.R.; Flanagan, L.B.; Yakir, D.; Bowling, D.R.; Still, C.J.; Buchmann, N.; Kaplan, J.O.; Berry, J.A. The application and interpretation of Keeling plots in terrestrial carbon cycle research. Global Biogeochem.Cycles 2003, 17, 1022, doi:10.1029/2001GB001850.

Pielke, R.A. Sr. Influence of the spatial distribution of vegetation and soils on the prediction of cumulus convective rainfall. Rev. Geophys. 2001, 39, 151-177.

Pietroniro, A.; Leconte, R. A review of Canadian remote sensing and hydrology, 1999-2003. Hydro. Processes 2005, 19, 285-301.

Plummer, S.E. Perspectives on combining ecological process models and remotely sensed data. Ecol. Model. 2000, 129, 169-186.

Ponton ,S; Flanagan, L.B.; Alstard, K; Johnson, B.G.; Morgenstern, K; Kljun, N; Black, T.A.; Barr, A.G. Comparison of ecosystem water-use efficiency among Douglas-fir forest, aspen forest and grassland using eddy covariance and carbon isotope techniques. Global Change Biol. 2006, 12, 294-310.

Porporato, A.; D'odorico, P.; Laio, F.; Rodriguez-Iturbe, I. Hydrologic Controls on Soil Carbon and Nitrogen Cycles. I. Modeling Scheme. Adv. Water Resour. 2003, 26, 4558.

Prentice, I.C.; Cramer, W.; Harrison, S.P.; Leemans, R.; Monserud, R.A.; Solomon, A.M. A global biome model based on plant physiology and dominance, soil properties, and climate. J. Biogeog. 1992, 19, 117-134. 
Prentice; I.C.; Farquhar, G.D.; Fasham, M.J.R. et al. In The carbon cycle and atmospheric carbon dioxide; Houghton, J.T., et al. Eds.; Cambridge University Press: Cambridge, UK, 2001, pp.183-238.

Prentice, K.; Fung, I.Y. The sensitivity of terrestrial carbon storage to climate change, Nature 1990, 346(6279), 48-51.

Prince, S. D.; Goward, S. N. Global primary production: A remote sensing approach, J. Biogeography, 1995, 22, 815-835.

Raich, J. W.; Rastetter, E. B.; Melillo, J. M. et al. Potential net primary productivity in SouthAmerica - application of a global-model, Ecological Applications, 1991, 1, 399-429.

Rannik, U.; Kolari, P.; Vesala, T.; Hari, P. Uncertainties in Measurement and Modelling of Net Ecosystem Exchange of a Forest. Agric. For. Meteor. 2006, 138, 244-257.

Ranson, K. J.; Kovacs, K.; Sun, G.; Kharuk, V. I. Disturbance recognition in the boreal forest using radar and Landsat-7. Canadian Journal of Remote Sensing, 2003 ,29, 271-285.

Reed, S.; Koren, V.; Smith, M.; Zhang, Z.; Moreda, F.; Seo, D.J. Overall distributed model intercomparison project results. J. Hydro. 2004, 298, 27-60.

Reichstein, M.; Falge, E.; Baldocchi, D. et al. On the separation of net ecosystem exchange into assimilation and ecosystem respiration: review and improved algorithm, Glob. Change Biol. , 2005, 11, 1424-1439.

Reichstein, M., Tenhunen, J. D., Roupsard, O., Ourcival, J. M., Rambal,S., Dore, S., and Valentini, R.: Ecosystem respiration in two Mediterranean veergreen Holm Oak forests: drought effects and decomposition dynamics, Funct. Ecol. , 2002, 16, 27-39.

Richardson, A. D.; Hollinger, D.Y.B.; George, G. et al. A multi-site analysis of random error in tower-based measurements of carbon and energy fluxes, Agricultural Forest Meteorology, 2006, 136, 1-18.

Ritchie, J.C.; Rango, A. Remote sensing applications to hydrology: introduction. Hydro. Sci. J. 1996, 41, 429-431.

Rodriguez-Iturbe, I. Ecohydrology: A hydrologic perspective of climate-soil-vegetation dynamics. Water Resour. Res. 2000, 36, 3-9.

Rodriguez-Iturbe, I.; Porporato, A.; Laio, F.; Ridolfi, L. Plants in Water-Controlled Ecosystems: Active Role in Hydrologic Processes and Response to Water Stress - I. Scope and General Outline. Adv. Water Resour. 2001, 24, 695-705.

Rouse, J.W.; Haas, R.H.; Schell, J.A. et al. Monitoring the vernal advancement and retrogradation (greenwave effect) of natural vegetation. In NASA/GSFC Type III Final Report. Greenbelt, 1974, MD: NASA

Roy, P.; Junchang, J.; Lewis, P. et al. Multi-temporal MODIS-Landsat data fusion for relative radiometric normalization, gap filling, and prediction of Landsat data. Remote Sensing of Environment, 2008, 112, 3112-3130.

Ruimy, A.; Jarvis, P. G.; Baldocchi, D. D.; Saugier, B. CO2 fluxes over plant canopies and solar radiation: A review, Advances in Ecological Research, 1995, 1-68.

Ruimy, A.; Kergoat, L.; Bondeau, A. Comparing global models of terrestrial net primary productivity (NPP): Analysis of differences in light absorption and light-use efficiency, Global Change Biology, 1999, 5, 56-64.

Running, S. W.; Baldocchi, D. D.; Turner, D. P. et al. A global terrestrial monitoring network integrating tower fluxes, flask sampling, ecosystem modeling and EOS satellite data, Remote Sensing of Environment, 1999, 70, 108-127. 
Running, S. W.; Nemani, R. R.; Heinsch, F. A. et al. A continuous satellite-derived measure of global terrestrial primary productivity: Future science and applications, Bioscience, 2004, 56, 547-560.

Running, S. W.; Thornton, P. E.; Nemani, R.; Glassy, J. M. Global terrestrial gross and net primary productivity from the Earth Observing System. In O. E. Sala, R. B. Jackson, \& H. A. Mooney (Eds.), Methods in Ecosystem Science, (pp. 44-57). , 2000, New York: Springer.

Running, S.W.; Coughlan, J.C. A general model of forest ecosystem processes for regional applications I. Hydrological balance, canopy gas exchange and primary production processes. Ecol. Model. 1998, 42, 125-154.

Running, S.W.; Nemani, R.R.; Heinsch, F.A.; Zhao, M.; Reeves, M.; Jolly, M. A continuous satellite-derived measure of global terrestrial primary productivity: Future science and applications. Bioscience 2004, 56, 547-560.

Saatchi, S.S.; Moghaddam, M. Estimation of crown and stem water content and biomass of boreal forests using polarimetric SAR imagery. IEEE Transactions on Geoscience and Remote Sensing, 2000, 38, 697-709.

Sass, G.Z.; Creed, I.F.: Bird's eye view of forest hydrology: novel approaches using remote sensing techniques. In D. Levia, D. Carlyle-Moses, \& T. Tanaka (eds), Forest Hydrology and Biogeochemistry: Synthesis of Past Research and Future Directions,(pp.4568) 2011, New York: Springer.

Schmid, H. P. Experimental design for flux measurements: matching scales of observations and fluxes, Agric For Meteorol. , 1997, 87, 179-200.

Schmugge, J.S.; Kustas, W.P.; Ritchie ,J.C.; Jackson, T.J.; Rango, A. Remote sensing in hydrology. Adv. Water Resour. 2002, 25, 1367-1385.

Schultz, G.A. Remote sensing applications to hydrology: runoff. Hydro. Sci. J. 1996, 41, 453475.

Schwalm, C.R.; Ek, A.R. Climate change and site: relevant mechanisms and modeling techniques. For. Ecol. Manage. 2001, 150, 241-258.

Seaquist, J.W.; Olsson, L.; Ard" O, J. A remote sensing-based primary production model for grassland biomes. Ecol. Model. 2003, 169, 131-155.

Sellers, P.J., et al. Modeling the exchange of energy, water, and carbon between continentals and the atmosphere. Science 1997, 275, 502-509.

Sellers, P.J.; Mintz, Y.; Sud, Y.C.; Dalcher, A. A Simple Biosphere Model (SiB) for Use Within General-Circulation Models. J. Atmos. Sci. 1986, 43, 505-531.

Sellers, P.J.; Randall, D.A.; Collatz, G.J. et al. A revised land surface parameterization (SiB2) for atmospheric GCMs. Part I: model formulation. J. Climat. 1996, 9, 676-05.

Seneviratne, S.I.; Luthi, D.; Litschi, M.; Schar C. Land-atmosphere coupling and climate change in Europe. Nature 2006, 443, 205-209.

Seth, A.; Giorgi, F.; Dickinson, R.E. Simulating fluxes from heterogeneous land surfaces: Explicit subgrid method employing the biosphere-atmosphere transfer scheme (BATS). J. Geophys. Res., 1994, 99(D9), 18,651-18,667.

Shen, S.; Leclerc, M. Y. How large must surface layer inhomogeneities be before they influence the convective boundary layer structure? A case study, Quart J Roy Meteorol Soc. , 1995, 121, 1209-1228.

Snyder, P.K.; Delire, C.L.; Foley, J.A. Evaluating the influence of different vegetation biomes on the global climate. Clim. Dyn. 2004, 23, 279-302. 
Sogachev, A.; Rannik, U.; Vesala, T. Flux footprints over complex terrain covered by heterogeneous forest, Agric. For. Meteorol. , 2004, 127, 142-158.

Stisen, S.; Jensen, K.H.; Sandholt, I.; Grimes D.I.F. A remote sensing driven distributed hydrological model of the Senegal River basin. J. Hydro. 2008, 354, 131-148.

Stoy, P. C.; Katul, G.; Siqueira, G. Separating the effects of climate and vegetation on evapotranspiration along a successional chronosequence in the southeastern US, Global Change Biol. , 2006, 12, 2115-2135.

$\mathrm{Su}, \mathrm{Z}$. Remote sensing of land use and vegetation for mesoscale hydrological studies. Inter. J. Remot. Sens. 2000, 21, 213-233.

$\mathrm{Su}, \mathrm{Z}$., The surface energy balance system (SEBS) for estimation of the turbulent heat fluxes. Hydro. Earth Sci. 2002, 6, 85-99.

Suits, N.S.; Denning, A.S.; Berry, J.A.; Still, C.J.; Kaduk, J.; Miller, J.B.; Baker I.T. Simulation of carbon isotope discrimination of the terrestrial biosphere. Global Biogeochem. Cycles 2005, 19, GB1017, doi:10.1029/2003GB002141.

Tans, P.P.; Fung, I.Y.; Takahashi, T. Observation Constraints on the global atmospheric $\mathrm{CO}_{2}$ budget. Science 1990, 247, 1431-1438.

Tarantola, A. Inverse Problem: Theory Methods for Data Fitting and Parameter Estimation. Elsevier, 1987, New York.

Tilford, S. Global habitability and Earth remote sensing. Philos. Trans. R. Soc. 1984 A 312(1519):115-18.

Treuhaft, R.N.; Asner, G.P.; Law, B.E.; Van Tuyl, S. Forest leaf area density profiles from the quantitative fusion of radar and hyperspectral data. Journal of Geophysical Research, 2002, 107, 4568-4580.

Treut, L.; Somerville, H. R.; Cubasch, U.; Ding, Y.; Mauritzen, C.; Mokssit, A.; Peterson T.; Prather, M. Historical Overview of Climate Change. In Climate Change 2007: The Physical Science Basis. Contribution of Working Group I to the Fourth Assessment Report of the Intergovernmental Panel on Climate Change Solomon, S., D. Qin, M. Manning, Z. Chen, M. Marquis, K.B. Averyt, M. Tignor and H.L. Miller Eds. Cambridge University Press, Cambridge, United Kingdom and New York, NY, USA, 2007; pp. 104-105.

Tucker, C.J.; Fung, I.Y.; Keeling, C.D.; Gammon, R. The relationship of global green leaf biomass to atmospheric CO2 concentrations. Nature , 1986 319:159-99.

Tucker, C.J. Red and photographic infrared linear combinations for monitoring vegetation. Remote Sens. Environ. 1979, 8(2):127-50.

Urbanski, S.; Barford, C.; Wofsy, S. Factors controlling CO2 exchange on timescales from hourly to decadal at Harvard Forest, J. Geophys. Res., 2007, 112, G02020, doi:10.1029/2006JG000293.

Verseghy, D.L. Class-a Canadian Land Surface Scheme for Gcms.1. Soil Model. Int. J. Climatol. 1999, 11, 111-133.

Verseghy, D.L.; McFarlane, N.A.; Lazare, M., CLASS: A Canadian land surface scheme for GCMs: II. Vegetation model and coupled runs. Int. J. Climatol. 1993, 13, 347-370.

Verstraeten, W. W.; Veroustraete, F.; Feyen, J. Assessment of evapotranspiration and soil moisture content across different scales of observation, Sensors, 2008, 8, 70-117.

Viterbo, P.; Beljaars, A.C.M.; An improved land surface parameterization scheme in the ECMWF model and its validation. J. Climat. 1995, 8, 2716-2748.

Wang, J.; Price, K.P.; Rich, P.M. Spatial patterns of NDVI in response to precipitation and temperature in the central Great Plains. Int. J. Remote Sens. 2001, 22, 3827-3844. 
Wang, S.; Grant, R.F.; Verseghy, D.L.; Black, T.A. Modeling carbon-coupled energy and water dynamics of boreal aspen forest in a general circulation model land surface scheme. Int. J. Climatol. 2002, 22, 1249-1265.

Wang, S.; Grant, R.F.; Verseghy, D.L.; Black, T.A. Modeling carbon dynamics of boreal forest ecosystems using the Canadian land surface scheme. Clim. Chang. 2002, 55, 451-477.

Wang, X.-C.; Chen, R.F.; Gardner, G.B. Sources and transport of dissolved and particulate organic carbon in the Mississippi River estuary and adjacent coastal waters of the northern Gulf of Mexico, Marine Chemistry, 2004, 89, 241- 256.

Warren, C.R.; Adams, M.A. Distribution of N. Rubisco and photosynthesis in Pinus pinaster and acclimation to light. Plant Cell Environ. 2001, 24, 597-609.

Wen, X.; Yu, G.; Sun, X.; Li, Q. et al. Soil moisture effect on the temperature dependence ofecosystem respiration in a subtropical Pinus plantation of southeastern China, Agric. For. Meteor. , 2006, 137, 166-175.

Williams, M.S.; Law, B.E.; Anthoni, P.M.;Unsworth, W.H. Use of a simulation model and ecosystems flux data to examine carbon-water interactions in ponderosa pine. Tree Physiol. 2001, 21, 287-298.

Wilson, K.B.; Baldocchi, D.D.; Hanson, P.J. Leaf age affects the seasonal pattern photosynthetic capacity and net ecosystem exchange of carbon in a deciduous forest. Plant Cell Environmen. 2001, 24, 571-583.

Wilson, K.B.; Baldocchi, D.D.; Hanson, P.J. Spatial and seasonal variability of photosynthetic parameters and their relationship to leaf nitrogen in a deciduous forest. Tree Physi. 2000, 20, 565-578.

Wu, J. D.; Wang, D.; Bauer, M. E. Image-based atmospheric correction ofQuickBird imagery of Minnesota cropland. Remote Sensing of Environment, 2005,99, 315-325.

Xiao, X. M.; Zhang, Q. Y.; Hollinger, D.; Aber, J.; Moore, B. Modeling gross primary production of an evergreen needleleaf forest using MODIS and climate data, Ecological Applications, 2005, 15, 954-969.

Xiao, X.; Boles, S.; Liu, J. Y.; Zhuang, D. F.; Liu, M. L. Characterization of forest types in Northeastern China, using multi-temporal SPOT-4 VEGETATION sensor data, Remote Sensing of Environment, 2002, 82, 335-348.

Xiao, X.; Hollinger D.; Aber, J. D.; Goltz, M.; Davidson, E.; Zhang, Q. and Moore III B. Satellite-based Modeling of Gross Primary Production in an Evergreen Needle leaf Forest, Remote Sensing Envir. , 2004, 89, 519 - 534.

Zhang, L. M.; Yu, G. R.; Sun, X. M. et al.; Liu, Y. F.; Xin, D.; Guan D. X.; Yan, J. H. Seasonal variations of ecosystem apparent quantum yield (a) and maximum photosynthesis rate (Pmax) of different forest ecosystems in China, Agric. For. Meteor. , 2006, 137, 176-187.

Zhang, Y.; Chen, W.; Cihlar, J. A process-based model for quantifying the impact of climate change on permafrost thermal regimes. J. Geophys. Res. 2003, 108(D22), 4695, doi:10.1029/2002JD003354.

Zhu, X.; Chen, J.; Gao, F.; Chen, X.; Masek J. An enhanced spatial and temporal adaptive reflectance fusion model for complex heterogeneous regions, Remote Sensing of Environment, 2010, doi:10.1016/j.rse.2010.05.032. 


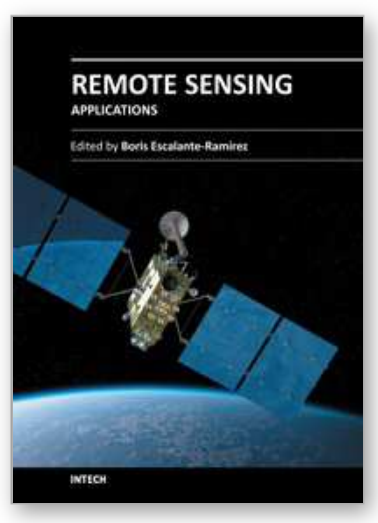

\author{
Remote Sensing - Applications \\ Edited by Dr. Boris Escalante
}

ISBN 978-953-51-0651-7

Hard cover, 516 pages

Publisher InTech

Published online 13, June, 2012

Published in print edition June, 2012

Nowadays it is hard to find areas of human activity and development that have not profited from or contributed to remote sensing. Natural, physical and social activities find in remote sensing a common ground for interaction and development. This book intends to show the reader how remote sensing impacts other areas of science, technology, and human activity, by displaying a selected number of high quality contributions dealing with different remote sensing applications.

\title{
How to reference
}

In order to correctly reference this scholarly work, feel free to copy and paste the following:

Baozhang Chen (2012). Coupled Terrestrial Carbon and Water Dynamics in Terrestrial Ecosystems:

Contributions of Remote Sensing, Remote Sensing - Applications, Dr. Boris Escalante (Ed.), ISBN: 978-95351-0651-7, InTech, Available from: http://www.intechopen.com/books/remote-sensing-applications/applicationof-remote-sensing-on-coupled-terrestrial-carbon-and-water-dynamics

\section{INTECH}

open science | open minds

\section{InTech Europe}

University Campus STeP Ri

Slavka Krautzeka 83/A

51000 Rijeka, Croatia

Phone: +385 (51) 770447

Fax: +385 (51) 686166

www.intechopen.com

\section{InTech China}

Unit 405, Office Block, Hotel Equatorial Shanghai

No.65, Yan An Road (West), Shanghai, 200040, China

中国上海市延安西路65号上海国际贵都大饭店办公楼 405 单元

Phone: +86-21-62489820

Fax: $+86-21-62489821$ 
(C) 2012 The Author(s). Licensee IntechOpen. This is an open access article distributed under the terms of the Creative Commons Attribution 3.0 License, which permits unrestricted use, distribution, and reproduction in any medium, provided the original work is properly cited. 